\title{
Fine particulate matter source apportionment using a hybrid chemical transport and receptor model approach
}

\author{
Y. Hu ${ }^{1}$, S. Balachandran ${ }^{1}$, J. E. Pachon ${ }^{1, *}$, J. Baek ${ }^{1, * *}$, C. Ivey ${ }^{1}$, H. Holmes ${ }^{1}$, M. T. Odman ${ }^{1}$, J. A. Mulholland ${ }^{1}$, and \\ A. G. Russell ${ }^{1}$ \\ ${ }^{1}$ School of Civil and Environmental Engineering, Georgia Institute of Technology, Atlanta, Georgia, USA
${ }^{*}$ now at: Program of Environmental Engineering, Universidad de La Salle, Bogota, Colombia
${ }^{* *}$ now at: Center for Global and Regional Environmental Research, University of Iowa, Iowa City, Iowa, USA
}

Correspondence to: Y. Hu (yh29@mail.gatech.edu)

Received: 31 August 2013 - Published in Atmos. Chem. Phys. Discuss.: 15 October 2013

Revised: 7 March 2014 - Accepted: 17 April 2014 - Published: 4 June 2014

\begin{abstract}
A hybrid fine particulate matter $\left(\mathrm{PM}_{2.5}\right)$ source apportionment approach based on a receptor model (RM) species balance and species specific source impacts from a chemical transport model (CTM) equipped with a sensitivity analysis tool is developed to provide physically and chemically consistent relationships between source emissions and receptor impacts. This hybrid approach enhances RM results by providing initial estimates of source impacts from a much larger number of sources than are typically used in RMs, and provides source-receptor relationships for secondary species. Further, the method addresses issues of source collinearities and accounts for emissions uncertainties. We apply this hybrid approach to conduct $\mathrm{PM}_{2.5}$ source apportionment at Chemical Speciation Network (CSN) sites across the US. Ambient $\mathrm{PM}_{2.5}$ concentrations at these receptor sites were apportioned to 33 separate sources. Hybrid method results led to large changes of impacts from CTM estimates for sources such as dust, woodstoves, and other biomass-burning sources, but limited changes to others. The refinements reduced the differences between CTM-simulated and observed concentrations of individual $\mathrm{PM}_{2.5}$ species by over $98 \%$ when using a weighted least-squares error minimization. The rankings of source impacts changed from the initial estimates, further demonstrating that CTM-only results should be evaluated with observations. Assessment with RM results at six US locations showed that the hybrid results differ somewhat from commonly resolved sources. The hybrid method also resolved sources that typical RM methods do not capture without extra measurement information for unique tracers. The method can be readily applied to large
\end{abstract}

domains and long (such as multi-annual) time periods to provide source impact estimates for management- and healthrelated studies.

\section{Introduction}

Fine particulate matter $\left(\mathrm{PM}_{2.5}\right)$ with an aerodynamic diameter less than $2.5 \mu \mathrm{m}$ is associated with adverse effects on human health (e.g., Dockery et al., 1993). From the perspective of linking health effects with air quality, and for assessing air quality management options, it is desirable to have the spatially and temporally resolved impacts of major emission sources. However, quantifying the impacts of individual sources on the ambient concentration of fine particulate matter, better known as source apportionment (SA), is challenging. A fundamental issue with any SA method is that there is no way to directly measure source impacts, and therefore it is difficult to assess the accuracy of source apportionment results. Tracer gases such as cyclic perfluoroalkanes and $\mathrm{SF}_{6}$ can be utilized to help quantify source impacts (Martin et al., 2011). However, such an approach is typically limited to assess a specific source's impact in special studies. Instead, source apportionment results are typically evaluated by comparing simulated concentrations of individual components and total mass of $\mathrm{PM}_{2.5}$ with observations (e.g., Watson et al., 2008; Viana et al., 2008b).

Receptor model (RM) approaches have long been used for $\mathrm{PM}_{2.5}$ source apportionment (Chow et al., 1992; Cooper and Watson, 1980; Liu et al., 2006; Martello et al., 2008; Reff 
et al., 2007; Schauer et al., 1996; Swietlicki et al., 1996; Thurston et al., 2011; Viana et al., 2008b; Watson, 1984; Watson et al., 2008; Xie et al., 2013). These methods, such as chemical mass balance (CMB) (Watson et al., 1984) or positive matrix factorization (PMF) (Pattero and Tapper, 1994), rely on using observed species concentrations of $\mathrm{PM}_{2.5}$ at a receptor(s) and solve a set of species balance equations to estimate source impacts. RM methods typically do not use emissions estimates or explicitly account for the chemical and physical processes that govern pollutant transport and transformation after being emitted from a specific source. To address these limitations, additional approaches are used (Blanchard et al., 2012; Chen et al., 2011; Lin and Milford, 1994; Roy et al., 2011; Watson et al., 2002; Wittig and Allen, 2008). In addition, receptor modeling typically accounts for a relatively small number of sources (on the order of ten out of hundreds in the inventory), comprising about $80 \%$ of the estimated emissions (Baek, 2009), leading to potential biases in the results. In RM methods, the common approach for assessing the accuracy of source apportionment results is to compare the calculated $\mathrm{PM}_{2.5}$ composition concentrations and total mass to observations, and if they compare well, it is assumed that the results are reasonable. However, this type of evaluation does not use a set of observations that are completely independent of the ones used to obtain the source impacts, although non-fitting species comparisons and other tests can be used to assist in the evaluation (USEPA, 2004). Further, similar estimated species concentrations, and hence similar performance, can result from very different combinations of source impacts. Results can also be quite sensitive to model inputs (e.g., source profiles for CMB), or the number of sources (or factors in PMF) used. Differences in source apportionment results for similar cases found between competing RM methods also suggest errors (Held et al., 2005; Laupsa et al., 2009; Lee et al., 2008; Lowenthal et al., 2010; Marmur et al., 2006; Rizzo and Scheff, 2007; Shi et al., 2009; Viana et al., 2008a; Watson et al., 2008). Several studies have tried to reconcile the results by refining source profiles and adding extra constraints (Lee and Russell, 2007; Marmur et al., 2007; Sheesley et al., 2007; Swietlicki et al., 1996; Watson et al., 2008). Extra species such as organic molecular markers and other unique tracers for certain sources have been utilized in RM modeling (Bullock et al., 2008; Lee et al., 2009; Schauer et al., 1996; Zheng et al., 2002) to improve the accuracy and identify additional sources, however measurements of those markers are not available from routine monitoring networks.

Source-oriented modeling (SM) approaches, such as chemical transport models (CTMs), follow the emission, transport, transformation, and loss of chemical species in the atmosphere to simulate ambient concentrations and source impacts. CTMs can compensate for limitations in RM methods (Burr and Zhang, 2011a, b; Doraiswamy et al., 2007; Held et al., 2005; Henze et al., 2009; Kleeman et al., 2007; Kwok et al., 2013; Lowenthal et al., 2010; Marmur et al.,
2006; Russell, 2008; Schichtel et al., 2006; Wagstrom et al., 2008; Wang et al., 2009; Ying et al., 2008) because they describe processes affecting source-receptor relationships from a first-principles basis. For example, compared with RMs, CTMs directly account for secondary formation of $\mathrm{PM}_{2.5}$ and nonlinearities in pollutant transformations and have the ability to quantify a more complete range of sources. Also, CTMs use knowledge of the specific location of emission sources in the region and their emission rates, and can provide spatially resolved source impacts across the modeling domain. An important strength of using CTMs for source apportionment is that model evaluation relies on independent data. However, estimates of source strengths and characteristics (e.g., diurnal and day-to-day variations) are viewed as highly uncertain, meteorological inputs of CTMs contain errors, and there continue to be uncertainties in how various processes are described. In addition, CTM methods utilize different approaches within a CTM framework to further estimate source impacts. These approaches include but are not limited to particulate matter source apportionment technology (PSAT) (Wagstrom et al., 2008), tagged species source apportionment (TSSA) (Wang et al., 2009), the integrated source apportionment method (ISAM) (Kowk et al., 2013), and various source and receptor sensitivity approaches (e.g., Koo et al., 2009; Henze et al., 2009). However, there are various theoretical limitations of each approach in determining source impacts in the complex atmospheric system (Koo et al., 2009; Burr and Zhang, 2011b). Due to these uncertainties/limitations and the required level of effort, SM approaches are not as widely used as RM methods for conducting $\mathrm{PM}_{2.5}$ source apportionment.

One way to take the advantages of SM approaches is to further improve SM source apportionment results by utilizing species concentration observations in a manner similar to RM approaches. Here, a hybrid SM-RM approach is developed and applied to obtain improved source impact estimates by integrating measurements with the CTM results, including uncertainty estimates of measurements and emissions. As developed, the method integrates the CMB method with CTM results at monitoring locations and measurement times by adding additional information and constraints in a species balance approach similar to CMB. The improved source impact estimates at these sparse locations can potentially be utilized to obtain source impact fields using spatial and temporal interpolation that take advantage of the initial CTM estimates across the domain and over the time period of interest. In this study the hybrid approach is applied to a $36 \mathrm{~km}$ resolution CTM simulation over North America. Our focus is to demonstrate the hybrid method by closely examining SM-RM source apportionment results across all sites and with more detail at select locations. 


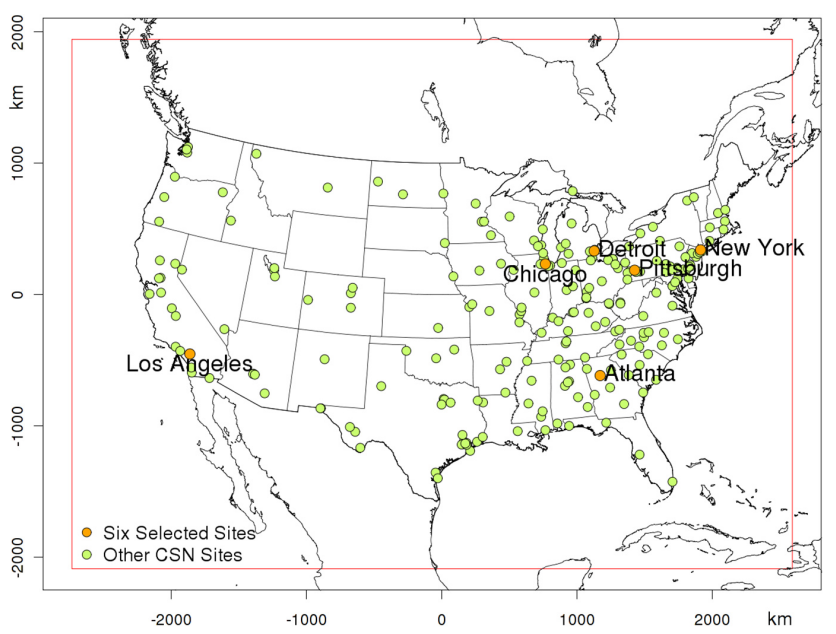

Figure 1. Modeling domain and monitoring sites used.

\section{Methods}

\subsection{CTM simulation and measurement data}

Simulated three-dimensional concentration fields of trace chemical species are obtained using the Community Multiscale Air Quality model (CMAQ) (Byun and Schere, 2006) version 4.5 (for using a newer version see Note $\mathrm{S} 1$ in the Supplement) with strict mass conservation (Hu et al., 2006), the SAPRC-99 chemical mechanism (Carter, 2000), and the aerosol module described in Binkowski and Roselle (2003). The modeling domain (Fig. 1) covers the continental United States (CONUS) as well as portions of Canada and Mexico with $36 \mathrm{~km} \times 36 \mathrm{~km}$ horizontal grids and 13 vertical layers of variable thickness extending from the surface to $70 \mathrm{hPa}$. CTMs applied with higher horizontal resolution would perform better in comparison of volume concentration to point measurement, especially for particulate matter, but computational cost increases rapidly. CTM modeling using $12 \mathrm{~km} \times 12 \mathrm{~km}$ grids covering the CONUS was restrictive at the time of this research but has started to become more practical recently.

We used meteorological fields generated by the FifthGeneration PSU/NCAR Mesoscale Model (MM5) (Grell et al., 1994), run with 35 vertical levels using four-dimensional data assimilation (FDDA), and the Pleim-Xiu land-surface model (Pleim and Xiu, 1995; Xiu and Pleim, 2001). Simulated meteorological fields were evaluated against surface hourly observations from the US and Canada (Table S1 in the Supplement); performance was well within the typical range for regional air quality modeling (Emery et al., 2001; Hanna and Yang, 2001).

Emissions inputs used were developed from a 2004 inventory that was projected from the 2002 National Emissions Inventory (NEI2002, obtained from http://www.epa. gov/ttn/chief/emch/index.html\#2002). Projection of the 2002 inventory to 2004 was conducted using growth factors obtained from the Economic Growth Analysis System (EGAS) version 4.0 and control efficiency data obtained from EPA for existing federal and local control strategies. In addition, US emissions from large $\mathrm{NO}_{\mathrm{x}}$ and $\mathrm{SO}_{2}$ point sources for 2004 were obtained from the continuous emissions monitoring (CEM) database (http://ampd.epa.gov/ampd/). The inventory has emissions of seven criteria pollutants including $\mathrm{PM}_{2.5}$. The Sparse Matrix Operator Kernel for Emissions (SMOKE) model (CEP, 2003) is used to process the emissions inventory and prepare gridded, CMAQ-ready emissions inputs. In SMOKE processing, $\mathrm{PM}_{2.5}$ emissions were split into major components (sulfate, nitrate, $\mathrm{EC}, \mathrm{OC}$, and other) using source-specific speciation profiles from the SPECIATE program (Simon et al., 2010). The component historically called "unidentified" in the emissions modeling process is called "other" here because this portion of $\mathrm{PM}_{2.5}$ is derived from measurements that provide the composition of the emissions and includes element species, which can be used to track source specific impacts on primary $\mathrm{PM}_{2.5}$. Spatial surrogates provided by the US EPA (http: //www.epa.gov/ttn/chief/emch/spatial/), derived from census and geographic information such as population, households, road networks, railroads, land use, etc. were used in SMOKE for spatially distributing different emission subcategories according to their source classification codes (SCCs). Monthly, weekly, and diurnal temporal profiles were used to allocate emissions by hour. While most temporal profiles were used nationwide, dozens of state-specific temporal profiles were also applied. For example, different diurnal profiles have been developed for prescribed burning emissions from different states. Therefore, emissions uncertainties and biases are not expected to be spatially or temporally uniform, especially on a daily basis.

We apply the above modeling system to simulate $\mathrm{PM}_{2.5}$ and gaseous concentrations for the month of January 2004, with 1-3 January as ramp-up days. The simulations of major $\mathrm{PM}_{2.5}$ and gaseous species were compared against measurements from multiple monitoring networks (Table S3 in the Supplement) with performance statistics well within the normal range of current state-of-the-art CTMs (Boylan and Russell, 2006; Simon, et al., 2012; Tesche et al., 2006). We chose to simulate a winter episode for a number of reasons: (1) wintertime provides a complete range of source sectors for a better evaluation of CTM source impact results. A summer episode would miss many important source sectors such as prescribed burns and open fires. (2) $\mathrm{PM}_{2.5}$ pollution episodes happen more frequently during the winter season, and there were many elevated $\mathrm{PM}_{2.5}$ measurements during the selected one-month-long period. (3) Secondary nitrate $\mathrm{PM}_{2.5}$ is much more abundant during winter and becomes a major portion of $\mathrm{PM}_{2.5}$, especially on the west coast. Although oxidation rates are lower during winter, sulfate and secondary organic aerosol (SOA) is still formed, especially in areas that are relatively warm during this period. 
To further evaluate source impacts, we also use measurements of 35 elements in $\mathrm{PM}_{2.5}$ that are collected at the Chemical Speciation Network (CSN) sites (Fig. 1) along with measurements of major $\mathrm{PM}_{2.5}$ components and total mass (Table S4 in the Supplement). Detection limit and measurement uncertainty were used to screen for measurements that are invalid or below the detection limit (DL). Values below the DL were set to one-half of the detection limit and the uncertainty was set to two-thirds of the DL (Marmur et al., 2006). Organic and elemental carbon measurements were artifact-corrected and converted from thermal optical transmittance (TOT) to thermal optical reflectance (TOR) equivalents using the method (Malm et al., 2011) recommended by US EPA (http://www.epa.gov/ttn/naaqs/ standards/pm/data/20120614Frank.pdf; see Note S2 in the Supplement). CMAQ (and other CTMs as well) does not explicitly simulate many elemental species in $\mathrm{PM}_{2.5}$. Compared to version 4.5, CMAQ v5.0 has several additional metal species (Appel et al., 2013), but its complete list of explicitly modeled elements - $\mathrm{Al}, \mathrm{Ca}, \mathrm{Fe}, \mathrm{Mg}, \mathrm{Mn}, \mathrm{K}, \mathrm{Na}, \mathrm{Si}$, and $\mathrm{Ti}$ - still does not cover all the measured elements. One way to derive simulated concentrations for elements that are not explicitly modeled is to utilize the modeled other $\mathrm{PM}_{2.5}$ concentration by splitting it with source contribution and source specific profile information (to be detailed in Sect. 2.2).

\subsection{CTM source apportionment}

Source impacts (and initial and boundary condition impacts) can be estimated using a Taylor series approach (Cohan et al., 2005):

$$
\begin{aligned}
S A_{i, j}^{\mathrm{CTM}}= & \sum_{k=1}^{K}\left[P_{j, k} \frac{\partial c_{i}}{\partial p_{j, k}}+\frac{P_{j, k}^{2}}{2} \frac{\partial^{2} c_{i}}{\partial p_{j, k}^{2}}+\sum_{l=1 ; l \neq k}^{L}\right. \\
& \left.\frac{P_{j, k} P_{j, l}}{2} \frac{\partial^{2} c_{i}}{\partial p_{j, k} \partial p_{j, l}}\right]+ \text { HOT, }
\end{aligned}
$$

where $S A_{i, j}^{\mathrm{CTM}}$ is the CTM simulated impact (source apportionment result) of source $j\left(j=1, \ldots J^{\mathrm{CTM}}\right.$, with $J^{\mathrm{CTM}}$ being the total number of sources that are included in the CTM simulation, treating initial and boundary conditions as "sources") on $\mathrm{PM}_{2.5}$ species $i(i=1, \ldots N$, with $N$ being the total number of such species) at the receptor; $P_{j, k}$ is either the emission rate of compound $k(k=1, \ldots, K)(k$ can be different than $i$, accounting for species transformations) from source $j$, i.e., $E_{j, k}$, or the initial or boundary concentration of compound $k ; l$ and $L$ are the same as $k$ and $K ; c_{i}$ is species $i$ 's concentration; $p_{j, k}\left(p_{j, l}\right)$ is the sensitivity parameter for $P_{j, k}\left(P_{j, l}\right)$; and HOT stands for high-order terms. The total impact of source $j$ on the $\mathrm{PM}_{2.5}$ concentration using CTM method $\left(S R_{j}^{\mathrm{CTM}}\right)$ is found by summing its impact on each species concentration:

$S R_{j}^{\mathrm{CTM}}=\sum_{i=1}^{N} S A_{i, j}^{\mathrm{CTM}}$.
Note that the above source apportionment approach is a sensitivity method. Sensitivity methods for estimating source impacts have been compared with other approaches such as PSAT (Koo et al., 2009; Burr and Zhang, 2011b). Though none of the methods were found to be perfect, the sensitivity method (with first-order sensitivities) was found to be proficient in determining the impacts of sources that have nonlinear effects among different species, such as motor vehicle emissions that include substantial amounts of multiple pollutants.

Here, for simplicity, we chose to ignore the higher-order terms (see Note S3 in the Supplement) and only used the first-order terms for source impact estimation:

$S A_{i, j}^{\mathrm{CTM}} \approx \sum_{k=1}^{K} P_{j, k} \frac{\partial c_{i}}{\partial p_{j, k}}=\sum_{k=1}^{K} S_{i, j, k}^{(1)}=S_{i, j}^{(1)}=P_{j} \frac{\partial c_{i}}{\partial p_{j}}$,

where $S_{i, j, k}^{(1)}$ is the semi-normalized first-order sensitivity of species $i$ 's concentration to emission rate (or initial and boundary conditions) of compound $k$ from source $j$, while $S_{i, j}^{(1)}$ is the similar first-order sensitivity to the emissions of all compounds from source $j$, which is defined as the response of species $i$ 's concentration $c_{i}$ to perturbations in a sensitivity parameter $p_{j}$ (a model parameter or input such as an emission rate, initial condition, or boundary condition) by scaling the local sensitivities $\left(\partial c_{i} / \partial p_{j}\right)$ by $P_{j}$ (the unperturbed or "base case" value of the sensitivity parameter). The notations for time and space dependencies are dropped for simplicity. $S_{i, j}^{(1)}$ is computed by CMAQ using the decoupled direct method (DDM) (Dunker, 1981, 1984) applied to three-dimensional air quality models (Cohan et al., 2005; Dunker et al., 2002; Hakami et al., 2004; Yang et al.,1997) and extended to include the ability to follow $\mathrm{PM}_{2.5}$ (called DDM-3D/PM hereafter) (Boylan et al., 2002, 2006; Koo et al., 2009; Napelenok et al., 2006).

Since first-order DDM-3D/PM sensitivities best approximate a small perturbation, we group the total emissions into 33 integrated source categories (a simple description of the source categories are in Table 1 and further detailed grouping information using SCC can be found in Table S2 in the Supplement). Most of the categories have a small portion of emissions compared to the total. We computed DDM3D/PM first-order sensitivity coefficients for each source except SEASALT, as well as boundary and initial conditions for which the sensitivity parameters are defined as the summation of all species. The sensitivity coefficients of boundary and initial conditions were found to be minimal and therefore ignored in our source impact calculations. For SEASALT we directly used the simulated concentrations of $\mathrm{Na}^{+}$and $\mathrm{Cl}^{-}$ from sea salt emissions in the model as sensitivities of $\mathrm{Na}^{+}$ or $\mathrm{Cl}^{-}$to SEASALT emissions. Sensitivities of other species (including other elements, ions, and total mass of $\mathrm{PM}_{2.5}$ ) to SEASALT emissions were derived by applying the composition profile (Table S5 in the Supplement) for each species 
relative to the $\mathrm{Na}^{+}$sensitivities. For the other 32 sources, element (metals and minerals) sensitivity coefficients that are not explicitly simulated by CMAQ are derived by applying composition profiles (Table S5 in the Supplement) for those elements relative to the modeled, source specific, other $\mathrm{PM}_{2.5}$ sensitivities, respectively. Similarly, we also derived these elements' simulated concentrations from the concentration of other $\mathrm{PM}_{2.5}$. The source composition profiles of all the 33 categories are assembled from the 86 profiles examined in Reff et al. (2009) by emissions-weighted averaging of corresponding member profiles (determined by SCC groupings).

The result of Eq. (3) can be compared with the CMB method, which is based on apportioning each species proportional to the relative amount of that species in the $\mathrm{PM}_{2.5}$ emissions from a source:

$S A_{i, j}^{\mathrm{CMB}}=\frac{E_{j, i}}{E_{j}} S R_{j}^{\mathrm{CMB}}=f_{i, j} S R_{j}^{\mathrm{CMB}}$,

where $f_{i, j}=\frac{E_{j, i}}{E_{j}}$ represents the original source profile used by $\mathrm{CMB}$, i.e., the emission fraction of species $i\left(E_{j, i}\right)$ of the total $\mathrm{PM}_{2.5}\left(E_{j}\right)$ emitted from source $j\left(j=1, \ldots J^{\mathrm{CMB}}\right.$, with $J^{\mathrm{CMB}}$ being the total number of emission sources that the CMB approach considers; source $j$ here can be different than the sources CTM includes) and $S R^{\mathrm{CMB}}$ is the CMBcalculated impact of source $j$ on total $\mathrm{PM}_{2.5}$ concentration. One can extend the definition of $f_{i, j}$ for CTMs using Eq. (5) that includes the source impacts on condensed secondary pollutants in the analysis. Hence, an effective $f_{i, j}^{*}$ is found as

$f_{i, j}^{*}=\frac{S A_{i, j}^{\mathrm{CTM}}}{S R_{j}^{\mathrm{CTM}}}=\frac{S_{i, j}^{(1)}}{\sum_{i=1}^{N} S_{i, j}^{(1)}}=\frac{\sum_{k=1}^{K} S_{i, j, k}^{(1)}}{\sum_{i=1}^{N} \sum_{k=1}^{K} S_{i, j, k}^{(1)}}$.

Equation (5) reveals that when there are no emissions of $\mathrm{PM}_{2.5}$ component $i$ from source $j, f_{i, j}^{*}$ can still be nonzero, as the source could still contribute to secondary production of $\mathrm{PM}_{2.5}$.

\subsection{CTM-CMB hybrid source apportionment ap- proach}

At monitoring locations, on days with sufficient $\mathrm{PM}_{2.5}$ composition measurements available, the following species balance equations can be built for a CMB solution:

$c_{i}^{\mathrm{obs}}=\sum_{j=1}^{J^{\mathrm{CMB}}} f_{i, j} S R_{j}^{\mathrm{CMB}}+e_{i}^{\mathrm{CMB}}$,

where $c_{i}^{\text {obs }}$ is the measured concentration for the $i$ th $\mathrm{PM}_{2.5}$ species, and $e_{i}^{\mathrm{CMB}}$ is the concentration prediction error to be minimized. CMB solves the species balance equations to calculate a set of $S R_{j}^{\mathrm{CMB}}$ using fixed source profiles $f_{i, j}$ (with uncertainties) that minimizes the weighted squared error in the simulated concentrations (Watson, 1984).

Likewise, similar species balance equations can be built at the same receptors using the initial source apportionments from CMAQ DDM-3D/PM results as follows:

$$
\begin{aligned}
c_{i}^{\mathrm{obs}} & =\sum_{j=1}^{J^{\mathrm{CTM}}} S A_{i, j}^{\mathrm{CTM}}+e_{i}^{\mathrm{CTM}}=\sum_{j=1}^{J^{\mathrm{CTM}}} \sum_{k=1}^{K} S_{i, j, k}^{(1)}+e_{i}^{\mathrm{CTM}} \\
& =\sum_{j=1}^{J^{\mathrm{CTM}}} S_{i, j}^{(1)} \cdot+e_{i}^{\mathrm{CTM}}
\end{aligned}
$$

The extension to using CTM results is shown in the second through fourth equalities, where $e_{i}^{\mathrm{CTM}}$ is the prediction error of CTM for the $i$ th $\mathrm{PM}_{2.5}$ species. This equation is applied at specific receptor locations and times. Note that here we only used the first-order DDM-3D/PM results for approximating $S A_{i, j}^{\mathrm{CTM}}$; however, for more accurate estimates of $S A_{i, j}^{\mathrm{CTM}}$, one can include higher-order sensitivity (e.g., Zhang et al., 2012) results as well if they are available and the source is large. Also, the formulation in Eq. (7) (and following equations) allows $S A_{i, j}^{\mathrm{CTM}}$ to be source impact estimates from any other methods, including PSAT, TSSA, ISAM, and other sensitivity-base methods.

Utilizing Eq. (7) we can evaluate the initial source apportionment results for a measurement at a receptor by calculating the square prediction error as

$$
\chi^{2}=\sum_{i=1}^{N}\left[\frac{\left(c_{i}^{\mathrm{obs}}-\sum_{j=1}^{J^{\mathrm{CTM}}} S A_{i, j}^{\mathrm{CTM}}\right)^{2}}{\sigma_{c_{i}^{\mathrm{obs}}}^{2}}\right],
$$

where $\sigma_{C_{i}^{\text {obs }}}$ is the uncertainty in the measured concentration of species $i$ obtained from the CSN measurement uncertainty.

Equation (8) also sheds light on an opportunity to further minimize the CTM's prediction error in a least-squares solution that mimics the CMB method. This leads to a new method of conducting source apportionment in an SM-RM hybrid approach. One way to achieve this is to calculate a new set of $S R_{j}^{C T M}$ using the extended $f_{i, j}^{*}$ that minimizes the weighted squared error in the simulated concentrations as follows:

$\chi^{2}=\sum_{i=1}^{N}\left[\frac{\left(c_{i}^{\mathrm{obs}}-\sum_{j=1}^{J^{\mathrm{CTM}}} f_{i, j}^{*} S R_{j}^{\mathrm{CTM}}\right)^{2}}{\sigma_{c_{i}^{\mathrm{obs}}}^{2}}\right]$.

While this approach is similar to CMB, it accounts for secondary contributions and other atmospheric processing using the extended $f_{i, j}^{*}$. If Eq. (9) alone were used to develop revised source impacts, it would not fully take into account 
Table 1. Emissions source categories used in the hybrid method application.

\begin{tabular}{llllll}
\hline Top-tier sectors & Combustion & On road & Non-road & Biomass burning & Industrial and others \\
\hline 33 source & COALCMB, & ORDIESEL, & AIRCRAFT, NRDIESEL, & AGRIBURN & BIOGENIC, \\
categories & DIESELCMB, & ORGASOLINE & NRFUELOIL, \\
& FUELOILCMB, & & NRGASOLINE, NRLPG, NRNA- & WPENFIRE, & OPIVESTOCK, \\
& LPGCMB, & & GAS, & PRESCRBURN, & MEATCORODUCT, \\
& NAGASCMB, & NROTHERS, RAILROAD & LWASTEBURN, & MINERALPRODUCT, \\
& OTHERCMB, & & WOODFUEL, & SEASALT, \\
& MEXCMB_M & & WOODSTOVE & SOLVENT, OTHERS
\end{tabular}

Note: COALCMB - coal combustion; DIESELCMB - diesel combustion; FUELOILCMB - fuel oil combustion; LPGCMB - liquid petroleum gas combustion; NAGASCMB - natural gas combustion; OTHERCMB - other fuel combustion; MEXCMB_M - Mexican combustion mix fuel; ORDIESEL - on-road diesel vehicles; ORGASOLINE - on-road gasoline vehicles; AIRCRAFT - aircraft operation in airports; NRDIESEL - non-road diesel; NRFUELOIL - non-road fuel oil; NRGASOLINE - non-road gasoline; NRLPG - non-road liquid petroleum gas; NRNAGAS - non-road natural gas; NROTHERS - non-road other fuel; RAILROAD - railroad; AGRIBURN - agricultural burn; WILDFIRE - wildfire; OPENFIRE open fire; PRESCRBURN - prescribed fire; LWASTEBURN - lawn waste burning; WOODFUEL - wood fuel boiler combustion; WOODSTOVE - woodstove and fireplace; BIOGENIC - biogenic; DUST - fugitive dust; LIVESTOCK - livestock mostly ammonia; METALPRODUCT - metal products; MEATCOOKING - meat cooking, frying, charcoal broil; MINERALPRODUCT - mineral products; SEASALT - sea salts; SOLVENT - solvents; OTHERS - others not in previous categories. See Table S2 in the Supplement for source classification codes grouped in each category.

the information provided by the CTM about the estimated size and location of various emission sources and their probable impact on pollutant concentrations at a receptor, i.e., the initial source impact estimates $S R_{j}^{\mathrm{CTM}}=\sum_{i=1}^{N} S A_{i, j}^{\mathrm{CTM}}$. As formulated in Eq. (9), this information is only used in the calculation of $f_{i, j}^{*}$, but the magnitudes of the source impacts are lost. Further, collinearity and uniqueness issues, such as different sources sharing similar source profiles, would still impact the solution of the system of equations.

Instead of the above approach, the CMB concept is extended to directly use the initial estimates of $S A_{i, j}^{\mathrm{CTM}}$ as well as the initial simulated concentrations $c_{i}^{\text {init }}$ from the CTM to refine the estimated source impacts. Defining $R_{j}$ as a scale factor applied to the initial estimate of impact of source $j$ (or initial or boundary conditions), $S A_{i, j}^{\text {refined }}$, the refined CTMsimulated impact of source $j$ on species $i$ is obtained as

$S A_{i, j}^{\text {refined }}=R_{j} S A_{i, j}^{\text {init }}$

Here $S A_{i, j}^{\text {init }}$ is the initial source impact $\left(S A_{i, j}^{\text {init }}\right.$ is the same as previous $S A_{i, j}^{\mathrm{CTM}}$ and is used from now on to distinguish from $S A_{i, j}^{\text {refined }}$ ). As such, refinements to source impacts can be found in a similar fashion to traditional CMB approaches by solving for $R_{j}$ to minimize $\chi^{2}$, where

$\chi^{2}=\sum_{i=1}^{N} \frac{\left(c_{i}^{\mathrm{obs}}-c_{i}^{\mathrm{init}}-\sum_{j=1}^{J^{\mathrm{CTM}}}\left(R_{j}-1\right) S A_{i, j}^{\mathrm{init}}\right)^{2}}{\sigma_{c_{i}^{\mathrm{obs}}}^{2}}$.

However, without further constraints $R_{j}$ can be physically unrealistic and would not account for the knowledge provided by the CTM about the source impacts or the uncertainties in emission estimates. Here, additional constraints and a term that penalizes moving away from the initial source im- pact estimates are added to find an optimized $R_{j}$ :

$$
\begin{aligned}
\chi^{2} & =\sum_{i=1}^{N}\left[\frac{\left(c_{i}^{\mathrm{obs}}-c_{i}^{\mathrm{init}}-\sum_{j=1}^{J^{\mathrm{CTM}}}\left(R_{j}-1\right) S A_{i, j}^{\mathrm{init}}\right)^{2}}{\sigma_{c_{i}^{\mathrm{obs}}}^{2}+\sigma_{S R_{i}^{2 \mathrm{CTM}}}^{2}}\right] \\
& +\Gamma \sum_{j=1}^{J \text { CTM }} \frac{\left(\ln R_{j}\right)^{2}}{\sigma_{\ln R_{j}}^{2}}
\end{aligned}
$$

where $\sigma_{S R_{i}^{\text {CTM }}}$ is the a priori uncertainty in CTM-derived total sources' impact on the $i$ th species, which is added to give weight for initial source impact estimates for different species and represents model errors. One can estimate $\sigma_{S R_{i}^{\text {CTM }}}$ as proportional to observed concentration $\sigma_{S R_{i}^{\text {CTM }}}=$ $\delta_{i} * c_{i}^{\text {obs }}$, with $\delta_{i}$ as normalized model errors. The second term of the equation accounts for uncertainties in the CTMderived individual source impacts due to emissions error. $\sigma_{\ln R_{j}}$ is the a priori uncertainty of the natural $\log$ of source $j$ 's scale factor. The logarithmic form is used as it has the same value on a relative basis (i.e., a 2 -fold overestimate is weighted the same as a 0.5 -fold underestimate). This naturally constrains $R_{j}$ to be positive. $\Gamma$ is introduced to balance the two terms in Eq. (12).

The objective function expressed as Eq. (12) can be minimized by using various optimization algorithms available for nonlinear optimization problems with constraints. We have tested multiple algorithms, including the algorithm of sequential least-squares quadratic programming (SLSQP) (Kraft, 1988, 1994) and L-BFGS, a limited-memory quasiNewton optimization function (Liu and Nocedal, 1989; Nocedal, 1980). With both the SLSQP and the L-BFGS method one can set lower and upper limits on $R_{j}$ for each individual source. We chose L-BFGS for our demonstration case study. As $R_{j}$ is optimized, the refined estimates of individual source impacts by species at a specific location are then 
given by Eq. (10). The level of remaining error in the refined concentration predictions can be found using Eq. (11).

\subsection{Application and case study}

The hybrid method was applied for January 2004 to calculate $\mathrm{PM}_{2.5}$ source impact scale factors at $164 \mathrm{CSN}$ monitors for which we had valid speciated $\mathrm{PM}_{2.5}$ data. By using the valid measurements at each of these CSN sites, the initial source impacts were evaluated through Eq. (12) to obtain impact scale factors and refined source impact estimates. The L-BFGS algorithm was used with box constraints that limited $R_{j}$ to be between 0.1 and 10.0 (different sets of limits have been tested, up to the range of between 0.02 and 50.0). Two steps were used to apply L-BFGS to find the final optimized $R_{j}$. First, an initial choice for $\Gamma$ was set as $\Gamma=\frac{N}{J \text { CTM }}=\frac{41}{33}=1.24$ to equally weigh the two terms in the objective function and obtain the initial optimal $R_{j}$. The choice of $\Gamma$ was examined using L-curve analysis (Fig. S1 in the Supplement). Then, the initial optimal $R_{j}$ were used to create a new $\Gamma$ as the value of the first term of the objective function divided by $J^{\mathrm{CTM}}$. The new $\Gamma$ was chosen to keep the prediction error relatively small but constraining the size of adjustments (Fig. S2 in the Supplement), and was applied to obtain the final optimized $R_{j}$. Here $\sigma_{\ln R_{j}}$ are determined by considering the daily emission estimates uncertainties for each source (Table S2 in the Supplement) derived from the literature (Hanna et al., 1998, 2001, 2005). In general, regulated sectors such as industrial, on-road and nonroad sources have lower uncertainties, non-regulated sectors such as residential related sources, dust and biomass burning have higher uncertainties, and sources with direct measurements (e.g., from CEMs) have the lowest. Because the refinements are applied daily, the uncertainties used account for the day-to-day variability in source strengths. For example, prescribed burning events can be quite variable in time. For traffic, day-specific emissions patterns are used, and so the source strength's variability is smaller. Sources for which direct emissions monitoring is available are assigned the lowest uncertainty. To determine $\sigma_{S R_{i}^{\mathrm{CTM}}}, \delta_{i}$ (Table S6 in the Supplement) are chosen as the typical normalized prediction errors of $\mathrm{PM}_{2.5}$ species as found in regional applications of state-ofthe-art CTM models (Appel et al., 2008; Boylan and Russell, 2006; Simon, et al., 2012; Tesche et al., 2006). Results were found to be not very sensitive to the range of values of $\sigma_{\ln R_{j}}$ and $\sigma_{S R_{i}^{\text {CTM }}}$ tested.

We chose six CSN sites, each representing a major US metropolitan area, for close examination of the method and further analysis. These six sites are located in the Atlanta, Chicago, Detroit, Los Angeles, New York, and Pittsburgh areas, representing urban/suburban locations across the country. Additional information for these six sites can be found in Tables S7 (basic site information) and Table S8 (emissions estimates surrounding each site) in the Supplement. For comparison, we also conducted CMB modeling at the At- lanta site using the same measurement data set and collected source apportionment results from the literature of the other five sites.

\section{Results}

\subsection{Impact scale factors and refined concentration predictions}

The hybrid method was applied to obtain $R_{j}$ and to further refine the initial source impact estimates. $R_{j}$ less than 1 means that the refined impact is reduced from the original (suggesting that the emissions are biased high or that the CTM is leading to a high bias in the source-receptor relationship), while larger than 1 means that the impact is increased from the initial simulation. The $R_{j}$ values obtained for the 33 sources ranged from 0.1 to 10 and have means between 0.15 and 1 , with sources of higher uncertainties having larger standard deviations (Table 2). In general, sources that are commonly considered as having high uncertainties were found to have $R_{j}$ values deviating the most from 1, while those sources considered less uncertain were found to have $R_{j}$ values near 1 . This is expected, in part because of the second term in the weighting function. The scale factors are also found to be quite consistent (i.e., in the same directions), in general, for the same source between locations and between days at the same location (Table S9 in the Supplement). Most significantly, $R_{j}$ 's cumulative distribution functions are found to be distinct between sources (Fig. S3 in the Supplement). This is true even between biomass-burning sources, although most of them have a similar composition in emissions (Fig. S3a in the Supplement). Dust, lawn waste burning (LWASTEBURN), and woodstove impacts (and other biomass-burning sources as well, although to a lesser extent) are found to be biased high $\left(R_{j}\right.$ values typically $\left.\sim 0.15\right)$. This is consistent with findings of prior studies (Baek, 2009; Chow et al., 2007; Tian et al., 2009) that emission rates for these sources were overestimated. Also, prescribed burning impacts are found to be biased low $\left(R_{j}\right.$ values being close to 10) a small portion of the time due to its high day-to-day variations. Typically, prescribed burning emissions are distributed uniformly over time in the inventories, while in reality burns occur on days with favorable burning conditions. For most other sources (Fig. S3b, c, and d in the Supplement), impact scale factors are typically closer to 1 , where most of the $R_{j}$ values are between 0.8 and 1.1, with the exception of metal processing, cooking processes, fuel oil and natural gas combustion, on-road gasoline vehicle, and other sources. These six sources have more diverse $R_{j}$ values among locations and/or between days.

An indication of the magnitude of the refinements can be found by comparing the initial and refined individual species concentrations to the observations and can be quantified using the weighted least-squares error (i.e., $\chi^{2}$ as expressed in 
Table 2. Calculated source impact scale factors $\left(R_{j}\right)$ across 164 CSN sites, January 2004: mean and standard deviation.

\begin{tabular}{lcc}
\hline Source & Mean & SD \\
\hline AGRIBURN & 0.702 & 0.334 \\
AIRCRAFT & 0.998 & 0.015 \\
BIOGENIC & 0.997 & 0.052 \\
COALCMB & 0.953 & 0.056 \\
DIESELCM & 1.000 & 0.001 \\
DUST & 0.150 & 0.269 \\
FUELOILC & 0.879 & 0.186 \\
LIVESTOCK & 0.989 & 0.043 \\
LPGCMB & 0.999 & 0.006 \\
LWASTEBU & 0.193 & 0.541 \\
MEATALPR & 0.738 & 0.224 \\
MEATCOOK & 0.817 & 0.305 \\
MEXCMB_M & 0.999 & 0.007 \\
MINERALP & 0.879 & 0.106 \\
NAGASCMB & 0.522 & 0.227 \\
NRDIESEL & 0.987 & 0.056 \\
NRFUELOI & 0.994 & 0.018 \\
NRGASOL & 0.988 & 0.054 \\
NRLPG & 1.000 & 0.003 \\
NRNAGAS & 1.000 & 0.001 \\
NROTHERS & 1.000 & 0.001 \\
OPENFIRE & 0.552 & 0.421 \\
ORDIESEL & 0.968 & 0.059 \\
ORGASOL & 0.862 & 0.172 \\
OTHERCMB & 0.910 & 0.130 \\
OTHERS & 0.521 & 0.222 \\
PRESCRBU & 0.961 & 1.122 \\
RAILROAD & 0.998 & 0.013 \\
SEASALT & 0.991 & 0.025 \\
SOLVENT & 0.895 & 0.163 \\
WILDFIRE & 0.836 & 0.256 \\
WOODFUEL & 0.904 & 0.184 \\
WOODSTOVE & 0.208 & 0.582 \\
\hline
\end{tabular}

Eq. (11)). The simulated concentrations are found to be improved substantially compared to the initial simulation after refining source impact estimates for major individual components and for most of the elements (Fig. 2 and Table 3). Note that several elements with very low ambient concentrations (e.g., near the measurement uncertainty) were found to have slightly deteriorated agreement with observations (Table 3). However, results show that the refined $\chi_{\mathrm{c}, \text { refined }}^{2}$ (Eq. (11) with obtained $R_{j}$ ), an overall measure for remaining error, was reduced from the original $\chi_{\mathrm{c} \text {, init }}^{2}$ by over $98 \%$ on average (Fig. 3). Because the CTM uses the original source speciation, the overall error will not go to zero unless the source fingerprints were correct. Further, the remaining error, $\chi_{\mathrm{c} \text {,refined }}^{2}$ includes the CTM's other input error such as meteorological bias and/or model limitations, e.g., the uncertainties involved in simulating nitrate or SOA formation. The magnitude of the remaining error itself can be one indicator
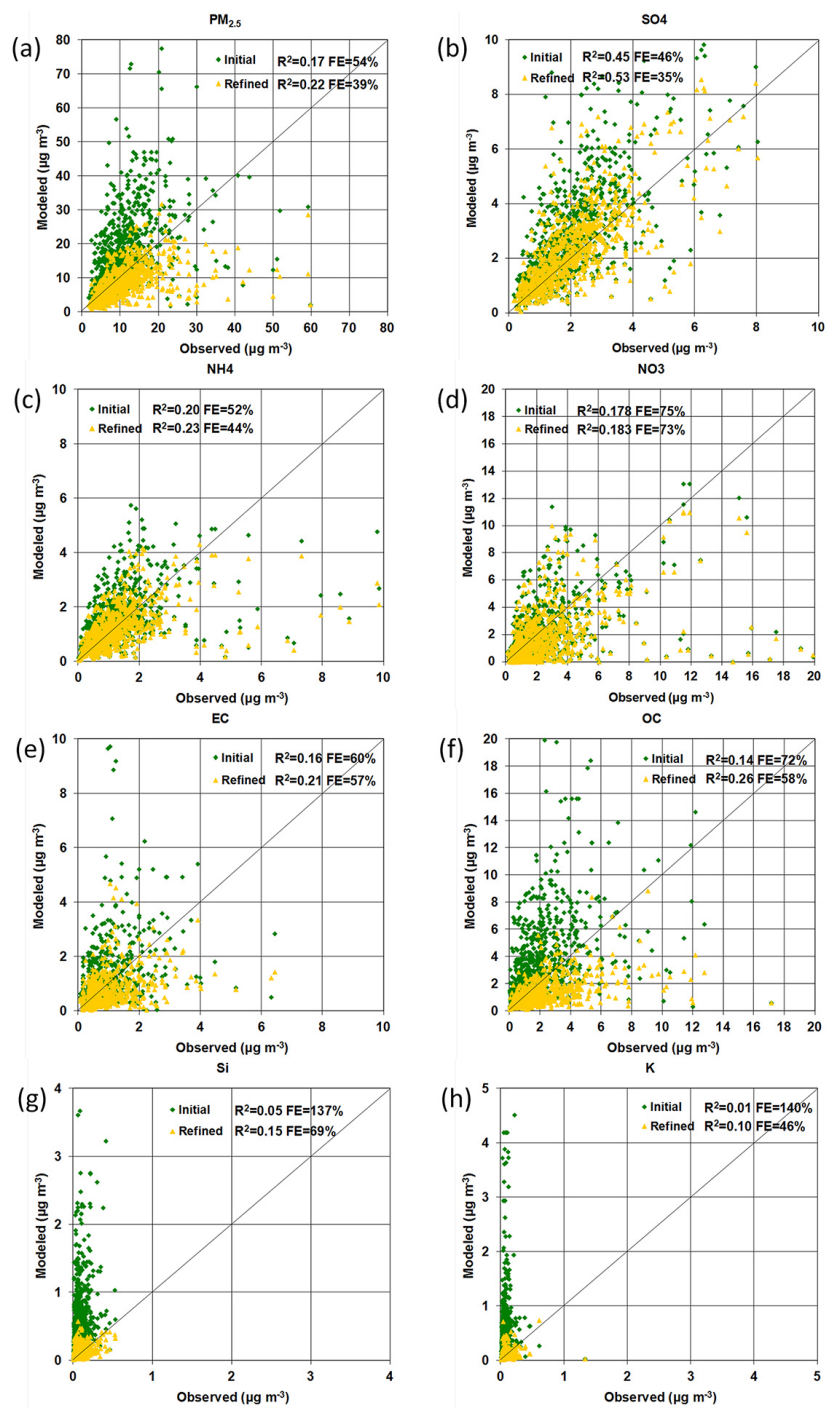

Figure 2. Scatter plots of initial and refined concentration predictions against observations for $\mathrm{PM}_{2.5}$ total mass and select components and elements: (a) $\mathrm{PM}_{2.5}$, (b) $\mathrm{SO}_{4}$, (c) $\mathrm{NH}_{4}$, (d) $\mathrm{NO}_{3}$, (e) $\mathrm{EC}$, (f) $\mathrm{OC},(\mathrm{g}) \mathrm{Si}$, and (h) K. Correlation $\left(R^{2}\right)$ and fractional error $\left(\mathrm{FE}=\frac{1}{N} \sum_{i=1}^{N} \frac{2 \times\left|C_{i}^{\text {sim }}-C_{i}^{\text {obs }}\right|}{\left(C_{i}^{\text {sim }}+C_{i}^{\text {obs }}\right)} \times 100 \%\right)$ are also shown.

of the uncertainty of the hybrid results (smaller error indicates more accurate results).

\subsection{Initial and refined CTM source impacts}

Significant day-to-day variations are found in the initial source impact estimates (e.g., Table S10 in the Supplement, as normalized by total source impact), being more pronounced for some sources, such as power plants (i.e., coal combustion) and industrial sources. For example, in Atlanta, power plants (coal combustion) can contribute over $30 \%$ on one day but only about $5 \%$ on other days (primarily as secondary sulfates). In Chicago, metal processing contributes 
Table 3. Initial and refined modeled concentrations vs. observed across 164 CSN sites, January 2004: average and standard deviation.

\begin{tabular}{|c|c|c|c|c|c|c|}
\hline \multirow[t]{2}{*}{ Species } & \multicolumn{2}{|c|}{ Observed } & \multicolumn{2}{|c|}{ Initial } & \multicolumn{2}{|c|}{ Refined } \\
\hline & $\operatorname{Avg}\left(\mu \mathrm{g} \mathrm{m}^{-3}\right)$ & $\mathrm{SD}\left(\mu \mathrm{g} \mathrm{m}^{-3}\right)$ & $\operatorname{Avg}\left(\mu g m^{-3}\right)$ & $\mathrm{SD}\left(\mu \mathrm{g} \mathrm{m}^{-3}\right)$ & $\operatorname{Avg}\left(\mu \mathrm{g} \mathrm{m}^{-3}\right)$ & $\mathrm{SD}\left(\mu \mathrm{g} \mathrm{m}^{-3}\right)$ \\
\hline PM25 & 11.31 & 7.19 & 17.89 & 11.88 & 8.80 & 4.74 \\
\hline OC25 & 2.12 & 1.98 & 3.85 & 3.72 & 1.29 & 1.00 \\
\hline EC25 & 0.81 & 0.75 & 1.07 & 1.13 & 0.62 & 0.59 \\
\hline NO325 & 2.61 & 3.05 & 2.07 & 2.11 & 1.87 & 1.89 \\
\hline NH425 & 1.27 & 1.11 & 1.50 & 0.98 & 1.21 & 0.75 \\
\hline SO425 & 2.03 & 1.28 & 2.84 & 1.82 & 2.30 & 1.48 \\
\hline $\mathrm{Na}$ & $7.6 \times 10^{-2}$ & $9.0 \times 10^{-2}$ & $1.2 \times 10^{-1}$ & $1.1 \times 10^{-1}$ & $3.6 \times 10^{-2}$ & $2.4 \times 10^{-2}$ \\
\hline $\mathrm{Mg}$ & $1.4 \times 10^{-2}$ & $1.7 \times 10^{-2}$ & $2.9 \times 10^{-2}$ & $2.3 \times 10^{-2}$ & $1.2 \times 10^{-2}$ & $8.6 \times 10^{-3}$ \\
\hline $\mathrm{Al}$ & $1.7 \times 10^{-2}$ & $1.9 \times 10^{-2}$ & $1.9 \times 10^{-1}$ & $1.6 \times 10^{-1}$ & $4.4 \times 10^{-2}$ & $2.8 \times 10^{-2}$ \\
\hline $\mathrm{Si}$ & $8.5 \times 10^{-2}$ & $7.4 \times 10^{-2}$ & $5.6 \times 10^{-1}$ & $4.8 \times 10^{-1}$ & $1.2 \times 10^{-1}$ & $7.6 \times 10^{-2}$ \\
\hline$P$ & $4.5 \times 10^{-3}$ & $1.6 \times 10^{-3}$ & $6.9 \times 10^{-3}$ & $5.3 \times 10^{-3}$ & $2.3 \times 10^{-3}$ & $1.4 \times 10^{-3}$ \\
\hline $\mathrm{Cl}$ & $5.3 \times 10^{-2}$ & $1.7 \times 10^{-1}$ & $4.5 \times 10^{-1}$ & $4.8 \times 10^{-1}$ & $8.7 \times 10^{-2}$ & $6.8 \times 10^{-2}$ \\
\hline $\mathrm{K}$ & $6.8 \times 10^{-2}$ & $7.1 \times 10^{-2}$ & $5.3 \times 10^{-1}$ & $6.5 \times 10^{-1}$ & $8.1 \times 10^{-2}$ & $7.7 \times 10^{-2}$ \\
\hline $\mathrm{Ca}$ & $4.4 \times 10^{-2}$ & $5.9 \times 10^{-2}$ & $1.9 \times 10^{-1}$ & $1.5 \times 10^{-1}$ & $5.0 \times 10^{-2}$ & $3.1 \times 10^{-2}$ \\
\hline $\mathrm{Ti}$ & $4.1 \times 10^{-3}$ & $3.7 \times 10^{-3}$ & $2.1 \times 10^{-2}$ & $1.8 \times 10^{-2}$ & $7.1 \times 10^{-3}$ & $4.8 \times 10^{-3}$ \\
\hline $\mathrm{V}$ & $2.4 \times 10^{-3}$ & $2.8 \times 10^{-3}$ & $1.5 \times 10^{-3}$ & $1.4 \times 10^{-3}$ & $5.2 \times 10^{-4}$ & $3.5 \times 10^{-4}$ \\
\hline $\mathrm{Cr}$ & $2.3 \times 10^{-3}$ & $5.7 \times 10^{-3}$ & $3.4 \times 10^{-3}$ & $4.6 \times 10^{-3}$ & $1.3 \times 10^{-3}$ & $1.0 \times 10^{-3}$ \\
\hline $\mathrm{Mn}$ & $3.6 \times 10^{-3}$ & $3.7 \times 10^{-2}$ & $5.6 \times 10^{-3}$ & $5.5 \times 10^{-3}$ & $1.5 \times 10^{-3}$ & $1.0 \times 10^{-3}$ \\
\hline $\mathrm{Fe}$ & $6.4 \times 10^{-2}$ & $9.7 \times 10^{-2}$ & $1.6 \times 10^{-1}$ & $1.4 \times 10^{-1}$ & $4.2 \times 10^{-2}$ & $2.7 \times 10^{-2}$ \\
\hline Co & $7.9 \times 10^{-4}$ & $4.2 \times 10^{-4}$ & $1.5 \times 10^{-4}$ & $1.3 \times 10^{-4}$ & $3.8 \times 10^{-5}$ & $2.6 \times 10^{-5}$ \\
\hline $\mathrm{Ni}$ & $2.0 \times 10^{-3}$ & $4.8 \times 10^{-3}$ & $3.9 \times 10^{-3}$ & $5.6 \times 10^{-3}$ & $1.6 \times 10^{-3}$ & $1.2 \times 10^{-3}$ \\
\hline $\mathrm{Cu}$ & $3.2 \times 10^{-3}$ & $4.9 \times 10^{-3}$ & $3.6 \times 10^{-3}$ & $4.8 \times 10^{-3}$ & $1.8 \times 10^{-3}$ & $1.3 \times 10^{-3}$ \\
\hline $\mathrm{Zn}$ & $1.6 \times 10^{-2}$ & $2.9 \times 10^{-2}$ & $1.2 \times 10^{-2}$ & $1.3 \times 10^{-2}$ & $3.4 \times 10^{-3}$ & $2.5 \times 10^{-3}$ \\
\hline $\mathrm{Ga}$ & $1.7 \times 10^{-3}$ & $9.0 \times 10^{-4}$ & $2.1 \times 10^{-5}$ & $2.2 \times 10^{-5}$ & $1.3 \times 10^{-5}$ & $9.1 \times 10^{-6}$ \\
\hline As & $1.7 \times 10^{-3}$ & $1.9 \times 10^{-3}$ & $2.6 \times 10^{-4}$ & $3.6 \times 10^{-4}$ & $8.6 \times 10^{-5}$ & $7.4 \times 10^{-5}$ \\
\hline $\mathrm{Se}$ & $1.8 \times 10^{-3}$ & $2.2 \times 10^{-3}$ & $1.9 \times 10^{-3}$ & $1.6 \times 10^{-3}$ & $1.3 \times 10^{-3}$ & $1.0 \times 10^{-3}$ \\
\hline $\mathrm{Br}$ & $3.3 \times 10^{-3}$ & $4.2 \times 10^{-3}$ & $2.9 \times 10^{-3}$ & $2.7 \times 10^{-3}$ & $8.5 \times 10^{-4}$ & $5.6 \times 10^{-4}$ \\
\hline $\mathrm{Rb}$ & $9.3 \times 10^{-4}$ & $5.1 \times 10^{-4}$ & $1.3 \times 10^{-3}$ & $1.1 \times 10^{-3}$ & $3.3 \times 10^{-4}$ & $2.3 \times 10^{-4}$ \\
\hline $\mathrm{Sr}$ & $1.7 \times 10^{-3}$ & $1.2 \times 10^{-3}$ & $1.5 \times 10^{-3}$ & $1.1 \times 10^{-3}$ & $6.7 \times 10^{-4}$ & $5.0 \times 10^{-4}$ \\
\hline $\mathrm{Zr}$ & $1.9 \times 10^{-3}$ & $1.3 \times 10^{-3}$ & $4.5 \times 10^{-4}$ & $3.7 \times 10^{-4}$ & $1.2 \times 10^{-4}$ & $7.3 \times 10^{-5}$ \\
\hline Mo & $4.0 \times 10^{-3}$ & $1.7 \times 10^{-3}$ & $8.4 \times 10^{-4}$ & $1.2 \times 10^{-3}$ & $4.6 \times 10^{-4}$ & $3.5 \times 10^{-4}$ \\
\hline $\mathrm{Ag}$ & $5.3 \times 10^{-3}$ & $3.4 \times 10^{-3}$ & $5.2 \times 10^{-4}$ & $8.1 \times 10^{-4}$ & $1.6 \times 10^{-4}$ & $1.3 \times 10^{-4}$ \\
\hline $\mathrm{Cd}$ & $7.2 \times 10^{-3}$ & $6.3 \times 10^{-3}$ & $4.2 \times 10^{-3}$ & $1.7 \times 10^{-2}$ & $1.0 \times 10^{-3}$ & $2.2 \times 10^{-3}$ \\
\hline In & $7.3 \times 10^{-3}$ & $4.2 \times 10^{-3}$ & $2.2 \times 10^{-4}$ & $2.2 \times 10^{-4}$ & $6.2 \times 10^{-5}$ & $4.4 \times 10^{-5}$ \\
\hline $\mathrm{Sn}$ & $1.0 \times 10^{-2}$ & $5.0 \times 10^{-3}$ & $1.3 \times 10^{-3}$ & $1.2 \times 10^{-3}$ & $6.5 \times 10^{-4}$ & $4.9 \times 10^{-4}$ \\
\hline $\mathrm{Sb}$ & $1.4 \times 10^{-2}$ & $1.1 \times 10^{-2}$ & $6.9 \times 10^{-4}$ & $8.6 \times 10^{-4}$ & $3.2 \times 10^{-4}$ & $2.3 \times 10^{-4}$ \\
\hline $\mathrm{Ba}$ & $1.5 \times 10^{-2}$ & $1.8 \times 10^{-2}$ & $9.0 \times 10^{-3}$ & $6.7 \times 10^{-3}$ & $4.9 \times 10^{-3}$ & $3.4 \times 10^{-3}$ \\
\hline $\mathrm{La}$ & $1.5 \times 10^{-2}$ & $1.9 \times 10^{-2}$ & $1.8 \times 10^{-3}$ & $1.8 \times 10^{-3}$ & $8.0 \times 10^{-4}$ & $5.7 \times 10^{-4}$ \\
\hline $\mathrm{Ce}$ & $1.9 \times 10^{-2}$ & $2.4 \times 10^{-2}$ & $2.1 \times 10^{-4}$ & $3.9 \times 10^{-4}$ & $8.4 \times 10^{-5}$ & $7.8 \times 10^{-5}$ \\
\hline $\mathrm{Hg}$ & $2.0 \times 10^{-3}$ & $9.3 \times 10^{-4}$ & $1.3 \times 10^{-5}$ & $1.0 \times 10^{-5}$ & $6.5 \times 10^{-6}$ & $4.4 \times 10^{-6}$ \\
\hline $\mathrm{Pb}$ & $4.8 \times 10^{-3}$ & $6.1 \times 10^{-3}$ & $1.9 \times 10^{-3}$ & $2.0 \times 10^{-3}$ & $6.4 \times 10^{-4}$ & $4.6 \times 10^{-4}$ \\
\hline
\end{tabular}

$20 \%$ on some days but less than $10 \%$ on other days. On-road gasoline impact can also vary significantly day to day, such as in Detroit, it varies from $\sim 18 \%$ to $\sim 3 \%$. Biomass-burning sources such as prescribed burns and agricultural burns contribute significantly on some days in Atlanta, but have virtually zero impact on other days.

Refined source impacts changed significantly from the initial CTM estimates for sources with high uncertainties, such as woodstoves and dust, as well as other biomass-burning sources, but changed much less or little for other sources (compare left and right columns in Tables 4 and S10 in the Supplement). Woodstoves and dust were top ranked at all six sites from the initial estimates; however, refinement significantly lowered those sources' impacts (Table 5). The differing adjustments between sources resulted in the rankings of top contributors changing. This indicates that estimates from 


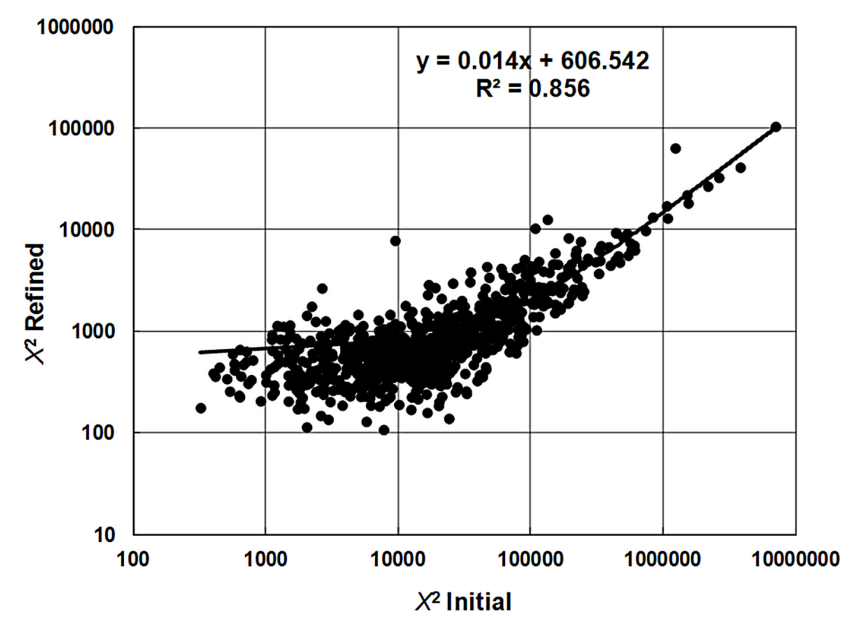

Figure 3. Refined $\chi_{\mathrm{c} \text {,refined }}^{2}$ vs. initial $\chi_{\mathrm{c} \text {,init }}^{2}$ (in logarithmic scales) for each measurement day during January 2004 at 164 CSN sites.

SM-only methods might result in misleading source apportionment outcomes due to the errors in emissions estimates on a specific day, as well as meteorological field and model parameter errors. For example, Marmur et al. (2006) found that the CMAQ-calculated impact of soil dust at Jefferson Street, Atlanta, GA (and other locations), was high when compared with two CMB estimates. This further supports that SM source apportionment results should be evaluated using measurements.

The hybrid method can separate sources with similar composition, e.g., woodstove and prescribed burns, especially noting the different changes of these two sources between their initial and refined impacts (Table S10 in the Supplement), as well as on-road and non-road diesel vehicles. This is because it starts from integrating estimated emissions from the inventory with source specific spatial and temporal resolutions, instead of starting from only the source composition like RMs do. In addition, with the hybrid method, secondary pollutants are directly apportioned to specific sources. For example, after the hybrid method refinement, livestock impacts advance in rank among top contributors in Midwestern cities: Chicago, Detroit, and Pittsburgh (Table 5), mostly through the secondary formation of ammonium and the associated nitrate from $\mathrm{NH}_{3}$ emissions. Also, the two most common major contributors across the cities become coal combustion (except Los Angeles, Table 5), mainly due to sulfate formation from $\mathrm{SO}_{2}$ emissions, and on-road gasoline vehicles, partially due to nitrate and $\mathrm{SOA}$ formation from $\mathrm{NO}_{\mathrm{x}}$ and VOC emissions.

\subsection{Comparison of refined source impacts with results from RM methods}

In order to compare with other source apportionment studies (see Table S11 in the Supplement for comparison with a CTM study's PSAT results), we first reduced the number of sources from 33 to 13 by aggregating the source impacts (Fig. 4 and Table S12 in the Supplement). The 13 aggregated sources are chosen to cover the range of various sources in different locations as identified in prior studies. Sources with similar composition, e.g., various gasoline and diesel vehicular sources, were merged accordingly. "AllOthers" included sources typically not resolved in traditional SA studies, e.g., livestock, biogenic and solvents as well as minor combustion and industrial sources. AllOthers (due to its large secondary contribution) as well as gasoline and diesel vehicles are top ranked in all six cities (Fig. 4 and Table S12 in the Supplement). To make hybrid results directly comparable to that of RM methods, we further separated the primary and secondary contributions in the aggregated source impacts and merged the secondary portions correspondingly into ammonium sulfates, ammonium nitrate, and secondary organic carbon (details are discussed in Note S4 in the Supplement). We compared the regrouped hybrid source impacts for a more direct comparison with RM methods conducted at the same location by this or prior studies (Coutant et al., 2003; Gildemeister et al., 2007; Maranche, 2006; Pham et al., 2008; Rizzo and Scheff, 2007) in Table 6. All the RM results were based on CSN measurements, though time periods for other RM results are typically longer than one year (details of RM model applications are found in Note S5 in the Supplement). Due to the different time periods used, we compare the major features such as what sources are being resolved and the relative contributions between certain sources.

The hybrid approach resolved extra sources (with the total impacts of extra sources ranging between 20 and $30 \%$ at the six sites) that are typically missing from $\mathrm{RM}$ results (Table 6). This is consistent with $\sim 20 \%$ of the emissions that Baek (2009) found were not captured in most RM source apportionment applications. For example, CMB-LGO, an extended CMB approach using the Lipschitz Global Optimizer (LGO) program (Marmur et al., 2005), did not capture the aircraft source impact at the Atlanta site (Balachandran et al., 2012) as the profile is uncertain and similar to diesel combustion. However, measurement (Herndon et al., 2008; Lee et al., 2011) and modeling (Unal et al., 2005) studies have both suggested that the commercial aircraft engine emissions from the Atlanta airport had significant impacts on local air quality including $\mathrm{PM}_{2.5}$ concentrations. Natural gas combustion and cooking process are two sources usually not resolved by RM methods using CSN data because their identification needs extra measurement information. For instance, CMB with particle-phase organic compounds as tracers using measurements collected at the Jefferson street site has identified that natural gas combustion had a $1.1 \%$ impact on $\mathrm{PM}_{2.5}$ in Atlanta (Zheng et al., 2002). Subramanian et al. (2007) used $\mathrm{CMB}$ with molecular markers and found that the impact of cooking processes range from 1 to $5 \%$ on $\mathrm{PM}_{2.5}$ concentrations in Pittsburgh. Compared to the hybrid results, primary impact estimates of coal combustion from RM methods are either missing or too low. This is because the trace element 
Table 4. January 2004 average initial and refined absolute $\left(\mu \mathrm{g} \mathrm{m}^{-3}\right)$ and percentage $(\%)$ source impacts on $\mathrm{PM}_{2.5}$ at the six sites.

\begin{tabular}{|c|c|c|c|c|c|c|c|c|c|c|c|c|c|c|c|c|c|c|c|c|c|c|c|c|}
\hline \multirow{3}{*}{$\begin{array}{l}\text { Category } \\
\text { AGRIBURN }\end{array}$} & \multicolumn{4}{|c|}{ Atlanta } & \multicolumn{4}{|c|}{ Chicago } & \multicolumn{4}{|c|}{ Detroit } & \multicolumn{4}{|c|}{ Los Angeles } & \multicolumn{4}{|c|}{ New York } & \multicolumn{4}{|c|}{ Pittsburgh } \\
\hline & \multicolumn{2}{|c|}{ Init. } & \multicolumn{2}{|c|}{ Refnd. } & \multicolumn{2}{|c|}{ Init. } & \multicolumn{2}{|c|}{ Refnd. } & \multicolumn{2}{|c|}{ Init. } & \multicolumn{2}{|c|}{ Refnd. } & \multicolumn{2}{|c|}{ Init. } & \multicolumn{2}{|c|}{ Refnd. } & \multicolumn{2}{|c|}{ Init. } & \multicolumn{2}{|c|}{ Refnd. } & \multicolumn{2}{|c|}{ Init. } & & nd. \\
\hline & 0.1 & 0.5 & 0.0 & 0.1 & 0.0 & 0.0 & 0.0 & 0.0 & 0.0 & 0.0 & 0.0 & 0.0 & 0.0 & 0.1 & 0.0 & 0.1 & 0.0 & 0.1 & 0.0 & 0.1 & 0.0 & 0.0 & 0.0 & 0.0 \\
\hline AIRCRAFT & 2.5 & 11.4 & 2.2 & 18.7 & 0.0 & 0.0 & 0.0 & 0.1 & 0.0 & 0.1 & 0.0 & 0.3 & 0.0 & 0.1 & 0.0 & 0.3 & 0.0 & 0.1 & 0.0 & 0.2 & 0.0 & 0.1 & 0.0 & 0.3 \\
\hline BIOGENIC & 0.9 & 4.3 & 0.9 & 7.8 & 0.1 & 0.3 & 0.1 & 0.9 & 0.1 & 0.6 & 0.1 & 1.4 & 1.5 & 3.7 & 1.5 & 9.6 & 0.3 & 1.4 & 0.3 & 2.7 & 0.2 & 1.1 & 0.2 & 1.9 \\
\hline COALCMB & 2.5 & 11.8 & 2.3 & 19.8 & 0.8 & 3.7 & 0.8 & 8.6 & 0.9 & 4.4 & 0.8 & 9.6 & 0.2 & 0.5 & 0.2 & 1.2 & 3.0 & 12.9 & 2.5 & 20.8 & 1.9 & 12.7 & 1.6 & 19.6 \\
\hline DIESELCMB & 0.0 & 0.0 & 0.0 & 0.0 & 0.0 & 0.0 & 0.0 & 0.0 & 0.0 & 0.1 & 0.0 & 0.1 & 0.0 & 0.0 & 0.0 & 0.1 & 0.0 & 0.0 & 0.0 & 0.1 & 0.0 & 0.0 & 0.0 & 0.1 \\
\hline DUST & 2.8 & 13.2 & 0.3 & 2.4 & 2.2 & 9.5 & 0.2 & 2.4 & 2.0 & 10.2 & 0.2 & 2.3 & 3.9 & 9.8 & 0.5 & 3.3 & 2.0 & 8.4 & 0.2 & 1.8 & 1.8 & 12.3 & 0.2 & 2.2 \\
\hline FUELOILCMB & 0.9 & 4.1 & 0.7 & 6.4 & 0.7 & 2.9 & 0.5 & 5.0 & 0.5 & 2.7 & 0.4 & 4.7 & 2.8 & 6.9 & 1.3 & 8.7 & 2.6 & 10.9 & 1.8 & 14.9 & 0.4 & 2.9 & 0.4 & 4.3 \\
\hline LIVESTOCK & 0.8 & 3.5 & 0.7 & 6.2 & 1.5 & 6.6 & 1.4 & 15.9 & 1.1 & 5.5 & 1.1 & 12.5 & 0.5 & 1.3 & 0.5 & 3.3 & 0.8 & 3.3 & 0.8 & 6.3 & 1.3 & 9.1 & 1.3 & 16.0 \\
\hline LPGCMB & 0.0 & 0.0 & 0.0 & 0.1 & 0.0 & 0.1 & 0.0 & 0.3 & 0.0 & 0.1 & 0.0 & 0.3 & 0.6 & 1.6 & 0.6 & 3.9 & 0.0 & 0.1 & 0.0 & 0.2 & 0.0 & 0.1 & 0.0 & 0.2 \\
\hline LWASTEBURN & 0.9 & 4.0 & 0.1 & 0.7 & 0.6 & 2.7 & 0.1 & 1.0 & 1.0 & 5.4 & 0.1 & 1.4 & 2.8 & 6.9 & 0.3 & 1.8 & 0.4 & 1.6 & 0.1 & 0.4 & 1.2 & 8.2 & 0.1 & 1.4 \\
\hline METALPRODUCT & 0.2 & 0.7 & 0.1 & 0.8 & 3.5 & 15.2 & 0.5 & 5.6 & 0.5 & 2.5 & 0.3 & 3.6 & 0.0 & 0.1 & 0.0 & 0.3 & 0.3 & 1.5 & 0.3 & 2.5 & 0.7 & 5.1 & 0.4 & 4.6 \\
\hline MEATCOOKING & 0.0 & 0.1 & 0.0 & 0.1 & 0.7 & 3.2 & 0.4 & 4.2 & 0.6 & 3.3 & 0.3 & 3.3 & 5.5 & 13.6 & 1.5 & 9.7 & 1.7 & 7.4 & 0.8 & 6.3 & 0.4 & 2.6 & 0.2 & 2.8 \\
\hline MEXCMB_M & 0.0 & 0.0 & 0.0 & 0.1 & 0.0 & 0.0 & 0.0 & 0.0 & 0.0 & 0.0 & 0.0 & 0.0 & 0.0 & 0.1 & 0.0 & 0.2 & 0.0 & 0.0 & 0.0 & 0.0 & 0.0 & 0.0 & 0.0 & 0.0 \\
\hline MINERALPRODUCT & 0.2 & 1.1 & 0.2 & 1.7 & 0.3 & 1.4 & 0.2 & 2.6 & 0.2 & 0.8 & 0.1 & 1.7 & 0.8 & 1.9 & 0.5 & 3.3 & 0.2 & 0.7 & 0.1 & 1.1 & 0.3 & 1.8 & 0.2 & 2.3 \\
\hline NAGASCMB & 0.8 & 3.7 & 0.3 & 2.2 & 3.1 & 13.6 & 0.8 & 8.7 & 2.2 & 11.3 & 0.8 & 9.0 & 3.5 & 8.7 & 0.9 & 5.8 & 1.4 & 6.0 & 0.6 & 5.1 & 0.7 & 4.8 & 0.3 & 3.7 \\
\hline NRDIESEL & 0.5 & 2.4 & 0.5 & 4.2 & 0.6 & 2.6 & 0.6 & 6.3 & 0.7 & 3.5 & 0.6 & 6.9 & 1.3 & 3.1 & 1.2 & 7.9 & 0.9 & 3.9 & 0.9 & 7.3 & 0.6 & 3.8 & 0.5 & 6.2 \\
\hline NRFUELOIL & 0.0 & 0.1 & 0.0 & 0.1 & 0.1 & 0.3 & 0.1 & 0.7 & 0.1 & 0.3 & 0.1 & 0.7 & 0.0 & 0.1 & 0.0 & 0.3 & 0.0 & 0.1 & 0.0 & 0.2 & 0.1 & 0.6 & 0.1 & 1.1 \\
\hline NRGASOLINE & 0.2 & 1.1 & 0.2 & 2.0 & 0.4 & 1.6 & 0.4 & 3.9 & 0.5 & 2.4 & 0.4 & 5.2 & 0.9 & 2.3 & 0.9 & 5.9 & 0.5 & 2.1 & 0.5 & 3.9 & 0.2 & 1.5 & 0.2 & 2.5 \\
\hline NRLPG & 0.0 & 0.0 & 0. & 0.1 & 0.0 & 0.1 & 0.0 & 0.2 & 0.0 & 0.1 & 0.0 & 0.2 & 0.0 & 0.1 & 0.0 & 0.2 & 0.0 & 0.0 & 0.0 & 0.0 & 0.0 & 0.1 & 0.0 & 0.1 \\
\hline NRNAGAS & 0.0 & 0.0 & 0.0 & 0.0 & 0.0 & 0.0 & 0.0 & 0.0 & 0.0 & 0.0 & 0.0 & 0.0 & 0.0 & 0.0 & 0.0 & 0.1 & 0.0 & 0.0 & 0.0 & 0.0 & 0.0 & 0.0 & 0.0 & 0.0 \\
\hline NROTHERS & 0.0 & 0.0 & 0.0 & 0.0 & 0.0 & 0.0 & 0.0 & 0.0 & 0.0 & 0.0 & 0.0 & 0.0 & 0.0 & 0.0 & 0.0 & -0.1 & 0.0 & 0.0 & 0.0 & 0.0 & 0.0 & 0.0 & 0.0 & 0.0 \\
\hline OPENFIRE & 0.2 & 0.9 & 0.0 & 0.2 & 0.0 & 0.0 & 0.0 & 0.0 & 0.0 & 0.0 & 0.0 & 0.0 & 0.0 & 0.0 & 0.0 & 0.1 & 1.5 & 6.4 & 0.2 & 1.4 & 0.0 & 0.3 & 0.0 & 0.2 \\
\hline ORDIESEL & 0.6 & 2.9 & 0.6 & 4.8 & 0.3 & 1.4 & 0.3 & 3.4 & 0.7 & 3.7 & 0.6 & 7.1 & 0.6 & 1.5 & 0.6 & 3.6 & 0.6 & 2.4 & 0.5 & 4.4 & 0.3 & 1.9 & 0.3 & 3.2 \\
\hline ORGASOLINE & 2.2 & 10.3 & 1.4 & 11.9 & 1.7 & 7.3 & 1.1 & 12.2 & 1.5 & 7.8 & 1.2 & 13.7 & 2.2 & 5.6 & 1.5 & 9.5 & 1.3 & 5.7 & 1.0 & 8.0 & 1.3 & 9.1 & 1.2 & 14.0 \\
\hline OTHERCMB & 0.1 & 0.6 & 0.1 & 0.7 & 1.2 & 5.3 & 0.7 & 7.4 & 0.2 & 0.9 & 0.2 & 1.8 & 0.1 & 0.3 & 0.1 & 0.6 & 0.1 & 0.5 & 0.1 & 0.9 & 0.1 & 0.7 & 0.1 & 1.1 \\
\hline OTHERS & 0.5 & 2.5 & 0.2 & 1.9 & 2.1 & 9.3 & 0.3 & 3.4 & 0.8 & 4.3 & 0.4 & 4.5 & 3.2 & 8.1 & 1.3 & 8.1 & 1.2 & 5.3 & 0.4 & 3.7 & 1.1 & 7.2 & 0.5 & 6.5 \\
\hline PRESCRB & 0.5 & 2.4 & 0.1 & 0.9 & 0.6 & 0.0 & 0.0 & 0.0 & 0.0 & 0.0 & 0.0 & 0.0 & 0.1 & 0.3 & 0.2 & 1.0 & 0.2 & 0.9 & 0.1 & 0.7 & 0.0 & 0.1 & 0.0 & 0.1 \\
\hline RAILROAD & 0.1 & 0.3 & 0.1 & 0.6 & 0.1 & 0.7 & 0.1 & 1.6 & 0.1 & 0.4 & 0.1 & 0.8 & 0.3 & 0.7 & 0.3 & 1.9 & 0.0 & 0.1 & 0.0 & 0.2 & 0.1 & 0.5 & 0.1 & 0.8 \\
\hline SEASALT & 0.0 & 0.0 & 0.0 & 0.0 & 0.0 & 0.0 & 0.0 & 0.0 & 0.0 & 0.0 & 0.0 & 0.0 & 0.0 & 0.0 & 0.0 & 0.0 & 0.0 & 0.0 & 0.0 & 0.0 & 0.0 & 0.0 & 0.0 & 0.0 \\
\hline SOLVENT & 0.2 & 1.1 & 0.2 & 1.8 & 0.5 & 2.0 & 0.2 & 2.3 & 0.2 & 1.0 & 0.1 & 1.7 & 0.6 & 1.4 & 0.5 & 3.3 & 0.4 & 1.6 & 0.3 & 2.5 & 0.1 & 0.9 & 0.1 & 1.4 \\
\hline WILDFIRE & 0.0 & 0.1 & 0.0 & 0.1 & 0.0 & 0.0 & 0.0 & 0.1 & 0.0 & 0.0 & 0.0 & 0.1 & 0.0 & 0.0 & 0.0 & 0.3 & 0.0 & 0.1 & 0.0 & 0.1 & 0.0 & 0.1 & 0.0 & 0.1 \\
\hline WOODFUEL & 0.1 & 0.3 & 0.1 & 0.4 & 0.0 & 0.1 & 0.0 & 0.2 & 0.0 & 0.2 & 0.0 & 0.5 & 0.0 & 0.1 & 0.0 & 0.1 & 0.1 & 0.4 & 0.1 & 0.6 & 0.0 & 0.1 & 0.0 & 0.2 \\
\hline WOODSTOVE & 3.6 & 16.8 & 0.4 & 3.1 & 2.3 & 10.1 & 0.3 & 2.7 & 5.4 & 28.1 & 0.5 & 6.4 & 8.6 & 21.3 & 0.9 & 5.5 & 3.7 & 16.0 & 0.4 & 3.6 & 1.8 & 12.4 & 0.3 & 3.0 \\
\hline Total impacts & 21.6 & 100. & 11.8 & 100 & 8 & 100. & 9.1 & 100. & 19.3 & 100. & 8.5 & 100. & 40.3 & 100. & 15.6 & 100 & 23.5 & 100 & 12.1 & 100 & 14.7 & 100. & 8.4 & 100. \\
\hline Observed concentration & & & & & & & & & & & & & & & & & & & & & & & & \\
\hline
\end{tabular}

Table 5. Initial vs. refined largest five contributing sources (January 2004).

\begin{tabular}{|c|c|c|c|c|c|c|}
\hline \multicolumn{2}{|c|}{ Site } & $1 \mathrm{st}$ & 2nd & 3rd & 4th & 5 th \\
\hline Atlanta & $\begin{array}{l}\text { Initial } \\
\text { Refined }\end{array}$ & $\begin{array}{l}\text { woodstove } \\
\text { coal combustion }\end{array}$ & $\begin{array}{l}\text { dust } \\
\text { aircraft }\end{array}$ & $\begin{array}{l}\text { coal combustion } \\
\text { on-road gasoline }\end{array}$ & $\begin{array}{l}\text { aircraft } \\
\text { biogenic }\end{array}$ & $\begin{array}{l}\text { on-road gasoline } \\
\text { fuel oil combustion }\end{array}$ \\
\hline Chicago & $\begin{array}{l}\text { Initial } \\
\text { Refined }\end{array}$ & $\begin{array}{l}\text { metal products } \\
\text { livestock }\end{array}$ & $\begin{array}{l}\text { natural gas combustion } \\
\text { on-road gasoline }\end{array}$ & $\begin{array}{l}\text { woodstove } \\
\text { natural gas combustion }\end{array}$ & $\begin{array}{l}\text { dust } \\
\text { coal combustion }\end{array}$ & $\begin{array}{l}\text { others } \\
\text { other fuel combustion }\end{array}$ \\
\hline Detroit & $\begin{array}{l}\text { Initial } \\
\text { Refined }\end{array}$ & $\begin{array}{l}\text { woodstove } \\
\text { on-road gasoline }\end{array}$ & $\begin{array}{l}\text { natural gas combustion } \\
\text { livestock }\end{array}$ & $\begin{array}{l}\text { dust } \\
\text { coal combustion }\end{array}$ & $\begin{array}{l}\text { on-road gasoline } \\
\text { natural gas combustion }\end{array}$ & $\begin{array}{l}\text { livestock } \\
\text { on-road diesel }\end{array}$ \\
\hline Los Angeles & $\begin{array}{l}\text { Initial } \\
\text { Refined }\end{array}$ & $\begin{array}{l}\text { woodstove } \\
\text { meat cooking }\end{array}$ & $\begin{array}{l}\text { meat cooking } \\
\text { biogenic }\end{array}$ & $\begin{array}{l}\text { dust } \\
\text { on-road gasoline }\end{array}$ & $\begin{array}{l}\text { natural gas combustion } \\
\text { fuel oil combustion }\end{array}$ & $\begin{array}{l}\text { others } \\
\text { others }\end{array}$ \\
\hline New York & $\begin{array}{l}\text { Initial } \\
\text { Refined }\end{array}$ & $\begin{array}{l}\text { woodstove } \\
\text { coal combustion }\end{array}$ & $\begin{array}{l}\text { coal combustion } \\
\text { fuel oil combustion }\end{array}$ & $\begin{array}{l}\text { fuel oil combustion } \\
\text { on-road gasoline }\end{array}$ & $\begin{array}{l}\text { dust } \\
\text { non-road diesel }\end{array}$ & $\begin{array}{l}\text { meat cooking } \\
\text { meat cooking }\end{array}$ \\
\hline Pittsburgh & $\begin{array}{l}\text { Initial } \\
\text { Refined }\end{array}$ & $\begin{array}{l}\text { coal combustion } \\
\text { coal combustion }\end{array}$ & $\begin{array}{l}\text { woodstove } \\
\text { livestock }\end{array}$ & $\begin{array}{l}\text { dust } \\
\text { on-road gasoline }\end{array}$ & $\begin{array}{l}\text { on-road gasoline } \\
\text { others }\end{array}$ & $\begin{array}{l}\text { livestock } \\
\text { non-road diesel }\end{array}$ \\
\hline
\end{tabular}

markers for coal combustion, $\mathrm{Se}$ and $\mathrm{Sr}$, were not detected consistently in CSN samples due to low signal-to-noise ratios (Chen et al., 2010).

Hybrid results estimated that total vehicle impacts (ranging from 14 to $22 \%$ ) were comparable to the RM results found at the same urban/suburban locations, with an exception in Chicago (Table S13 in the Supplement). In Chicago, Rizzo and Scheff (2007) also conducted PMF modeling using the same composite data, and their PMF results differ from $\mathrm{CMB}$ results, e.g., for biomass burning ( $5 \%$ vs. $11 \%$ ) and vehicle ( $23 \%$ vs. $31 \%$ ) source impacts. The PMF results were closer to the hybrid findings. At three of the four sites where the RM methods separated vehicle impacts between diesel and gasoline, the hybrid results do not agree with the RM methods on the diesel-gasoline split (Table S13 in the Supplement): the hybrid method found higher impacts of diesel vs. gasoline (by a factor of 2.0-2.6), while the RMs found the opposite (0.28-0.49). The ratios of diesel / gasoline emissions surrounding the sites are in the range of 1.7-3.6 (Table S13 in the Supplement). Subramanian et al. (2006) 
Table 6a. Refined source impacts results regrouped to 13 primary sources and compared to results from using RM methods: Atlanta, Chicago, and Detroit.

\begin{tabular}{|c|c|c|c|c|c|c|c|c|c|c|c|c|}
\hline \multirow{2}{*}{$\begin{array}{l}\text { Metro area (site ID) } \\
\text { Study method }\end{array}$} & \multicolumn{4}{|c|}{ Atlanta (130890002) } & \multicolumn{4}{|c|}{ Chicago (170310076) } & \multicolumn{4}{|c|}{ Detroit (261630001) } \\
\hline & \multicolumn{2}{|c|}{ Hybrid } & \multicolumn{2}{|c|}{$\begin{array}{l}\text { CMB-LGO } \\
\text { (this study) }\end{array}$} & \multicolumn{2}{|c|}{ Hybrid } & \multicolumn{2}{|c|}{$\begin{array}{c}\text { CMB } \\
\text { (Rizzo and Scheff, 2007) }\end{array}$} & \multicolumn{2}{|c|}{ Hybrid } & \multicolumn{2}{|c|}{$\begin{array}{c}\text { PMF } \\
\text { (Gildemeister et al., 2007) }\end{array}$} \\
\hline Period of measurements & \multicolumn{2}{|c|}{ Jan 2004} & \multicolumn{2}{|c|}{ Jan 2004} & \multicolumn{2}{|c|}{ Jan 2004} & \multicolumn{2}{|c|}{$2001-2003$} & \multicolumn{2}{|c|}{ Jan 2004} & \multicolumn{2}{|c|}{ Dec 2000-Apr 2005} \\
\hline $\begin{array}{l}\text { Source (primary and } \\
\text { secondary impacts separated) }\end{array}$ & $\mu \mathrm{g} \mathrm{m}^{-3}$ & $\%$ & $\mu \mathrm{g} \mathrm{m}^{-3}$ & $\%$ & $\mu \mathrm{g} \mathrm{m}^{-3}$ & $\%$ & $\mu \mathrm{g} \mathrm{m}^{-3}$ & $\%$ & $\mu \mathrm{g} \mathrm{m}^{-3}$ & $\%$ & $\mu \mathrm{g} \mathrm{m}^{-3}$ & $\%$ \\
\hline LDGV* $^{*}$ & 0.45 & 3.9 & 1.39 & 13.7 & 0.38 & 4.2 & 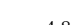 & & 0.60 & 7.1 & 2.53 & 15.0 \\
\hline $\mathrm{HDDV}^{*}$ & 1.20 & 10.2 & 0.59 & 5.9 & 0.83 & 9.2 & 4.8 & 31 & 1.19 & 14.0 & 0.67 & 4.2 \\
\hline DUST $^{*}$ & 0.28 & 2.4 & 0.18 & 1.8 & 0.22 & 2.4 & 0.39 & 2 & 0.19 & 2.3 & 1.29 & 8.0 \\
\hline BURN* & 0.60 & 5.1 & 1.06 & 10.4 & 0.35 & 3.9 & 1.71 & 11 & 0.68 & 8.1 & 0.51 & 3.2 \\
\hline COALCMB* & 0.64 & 5.4 & 0.01 & 0.1 & 0.31 & 3.4 & 0.19 & 1 & 0.25 & 3.0 & & \\
\hline MEATCOOKING* & 0.01 & 0.1 & & & 0.38 & 4.2 & & & 0.27 & 3.2 & & \\
\hline SEASALT $^{*}$ & $2.0 \times 10^{-3}$ & $1.7 \times 10^{-2}$ & & & $1.8 \times 10^{-4}$ & $1.9 \times 10^{-3}$ & $0.21^{* *}$ & 1 & $1.9 \times 10^{-4}$ & $2.3 \times 10^{-3}$ & $0.57^{* *}$ & 4.0 \\
\hline METALPRODUCT* & 0.06 & 0.5 & & & 0.41 & 4.5 & 0.31 & 2 & 0.20 & 2.4 & 0.51 & 3.2 \\
\hline MINERALPRODUCT* & 0.12 & 1.0 & & & 0.19 & 2.1 & & & 0.10 & 1.2 & & \\
\hline NATURALGAS* & 0.19 & 1.6 & & & 0.52 & 5.8 & & & 0.58 & 6.8 & & \\
\hline FUELOIL* & 0.09 & 0.7 & & & 0.15 & 1.6 & & & 0.10 & 1.2 & & \\
\hline AIRCRAFT* & 2.11 & 17.9 & & & 0.01 & 0.1 & & & 0.02 & 0.2 & & \\
\hline AllOthers* & 0.56 & 4.7 & & & 0.70 & 7.8 & & & 0.45 & 5.3 & & \\
\hline AMSULFT & 4.06 & 34.5 & 3.45 & 34.1 & 2.07 & 22.8 & 4.79 & 31 & 2.46 & 29.1 & 4.99 & 31.1 \\
\hline AMNITR & 0.84 & 7.2 & 2.25 & 22.3 & 2.47 & 27.3 & 3.18 & 20 & 1.26 & 14.8 & 4.49 & 28.0 \\
\hline OTHROC & 0.56 & 4.8 & 1.19 & 11.7 & 0.07 & 0.8 & & & 0.10 & 1.2 & & \\
\hline Total impacts & 11.78 & 100.0 & 10.11 & 100.0 & 9.06 & 100.0 & 15.58 & 99 & 8.46 & 100.0 & 15.56 & 96.7 \\
\hline $\begin{array}{l}\text { Modeled concentration }\left(\mu \mathrm{g} \mathrm{m}^{-3}\right) \\
\text { Observed concentrations }\left(\mu \mathrm{g} \mathrm{m}^{-3}\right)\end{array}$ & & & $\begin{array}{l}10 . \\
12 .\end{array}$ & & & & & & & & & \\
\hline
\end{tabular}

Table 6b. Refined source impacts results regrouped to 13 sources and compared to results from using RM methods: Los Angeles, New York, and Pittsburgh.

\begin{tabular}{|c|c|c|c|c|c|c|c|c|c|c|c|c|}
\hline \multirow{2}{*}{$\begin{array}{l}\text { Metro area } \\
\text { Study method }\end{array}$} & \multicolumn{4}{|c|}{ Los Angeles (060658001) } & \multicolumn{4}{|c|}{ New York (360050083) } & \multicolumn{4}{|c|}{ Pittsburgh (420030008) } \\
\hline & \multicolumn{2}{|c|}{ Hybrid } & \multicolumn{2}{|c|}{$\begin{array}{c}\text { CMB } \\
\text { (Pham et al., 2008) }\end{array}$} & \multicolumn{2}{|c|}{ Hybrid } & \multicolumn{2}{|c|}{$\begin{array}{c}\text { PMF } \\
\text { (Coutant et al., 2003) }\end{array}$} & \multicolumn{2}{|c|}{ Hybrid } & \multicolumn{2}{|c|}{$\begin{array}{c}\text { PMF } \\
\text { (Maranche, 2006) }\end{array}$} \\
\hline Period of measurements & \multicolumn{2}{|c|}{ Jan 2004} & \multicolumn{2}{|c|}{ Apr 2004-Mar 2005} & \multicolumn{2}{|c|}{ Jan 2004} & \multicolumn{2}{|c|}{3 Sep 2000-29 Jan 2002} & \multicolumn{2}{|c|}{ Jan 2004} & \multicolumn{2}{|c|}{ Jul 2003-Aug 2005} \\
\hline $\begin{array}{l}\text { Source (primary and } \\
\text { secondary impacts separated) }\end{array}$ & $\mu \mathrm{g} \mathrm{m}^{-3}$ & $\%$ & $\mu g \mathrm{~m}^{-3}$ & $\%$ & $\mu g \mathrm{~m}^{-3}$ & $\%$ & $\mu \mathrm{g} \mathrm{m}^{-3}$ & $\%$ & $\mu g \mathrm{~m}^{-3}$ & $\%$ & $\mu \mathrm{g} \mathrm{m}^{-3}$ & $\%$ \\
\hline LDGV* $^{*}$ & 0.93 & 6.0 & 0.85 & 3.7 & 0.72 & 6.0 & 25 & 155 & 0.37 & 4.5 & 1.37 & 9.5 \\
\hline $\mathrm{HDDV}^{*}$ & 1.87 & 12.0 & 2.54 & 11.1 & 1.56 & 13.0 & 2.5 & 15.5 & 0.82 & 9.9 & 0.68 & 4.7 \\
\hline DUST* & 0.52 & 3.3 & 0.78 & 3.4 & 0.21 & 1.8 & 1.0 & 6.0 & 0.18 & 2.2 & 1.18 & 8.2 \\
\hline BURN* & 1.27 & 8.2 & 0.38 & 1.6 & 0.75 & 6.2 & & & 0.39 & 4.8 & $2.4^{* * * *}$ & 16.7 \\
\hline COALCMB* $^{*}$ & 0.03 & 0.2 & & & 1.32 & 10.9 & & & 0.87 & 10.5 & & \\
\hline MEATCOOKING* & 1.51 & 9.7 & 1.44 & 6.3 & 0.75 & 6.2 & & & 0.23 & 2.8 & & \\
\hline SEASALT $^{*}$ & $3.2 \times 10^{-3}$ & $2.0 \times 10^{-2}$ & 1.38 & 6.0 & $2.0 \times 10^{-3}$ & $1.7 \times 10^{-2}$ & & & $2.0 \times 10^{-4}$ & $2.5 \times 10^{-3}$ & & \\
\hline METALPRODUCT* & 0.02 & 0.1 & & & 0.09 & 0.8 & 0.3 & 1.9 & 0.27 & 3.3 & & \\
\hline MINERALPRODUCT* & 0.39 & 2.5 & 0.71 & 3.1 & 0.09 & 0.8 & & & 0.14 & 1.7 & & \\
\hline NATURALGAS* & 0.68 & 4.4 & & & 0.49 & 4.1 & & & 0.23 & 2.7 & & \\
\hline FUELOIL* & 0.80 & 5.1 & 0.27 & 1.2 & 0.62 & 5.2 & 1.2 & 7.6 & 0.07 & 0.8 & $0.45^{* * * * *}$ & 3.1 \\
\hline AIRCRAFT* & 0.01 & 0.1 & & & 0.02 & 0.2 & & & 0.02 & 0.3 & & \\
\hline AllOthers* & 1.93 & 12.4 & & & 0.71 & 5.9 & $1.8^{* * *}$ & 11.3 & 0.38 & 4.6 & & \\
\hline AMSULFT & 2.47 & 15.9 & 4.51 & 19.7 & 4.24 & 35.2 & 5.3 & 32.9 & 3.10 & 37.4 & 5.49 & 38.2 \\
\hline AMNITR & 2.32 & 14.9 & 10.08 & 44.0 & 0.32 & 2.6 & 4.1 & 25.4 & 1.10 & 13.3 & 2.81 & 19.5 \\
\hline OTHROC & 0.79 & 5.1 & & & 0.16 & 1.3 & & & 0.12 & 1.4 & & \\
\hline Total impacts & 15.56 & 100.0 & 22.93 & 100.0 & 12.05 & 100.0 & 16.1 & 100.0 & 8.31 & 100.0 & 14.4 & 100.0 \\
\hline $\begin{array}{l}\text { Modeled concentration }\left(\mu \mathrm{g} \mathrm{m}^{-3}\right) \\
\text { Observed concentrations }\left(\mu \mathrm{g} \mathrm{m}^{-3}\right)\end{array}$ & 16. & 49 & & & 13 & & & & & 64 & 14.4 & \\
\hline
\end{tabular}

${ }^{*}$ Primary impacts only, secondary portion of the impacts are removed from these sources and merged into the secondary sources: AMSULFT - ammonium sulfate plus ammonium bisulfate; AMNITR - ammonium nitrate; and OTHROC - secondary organic

carbon.
${ }^{* *}$ Road salts. ${ }^{* * *}$ Industrial. ${ }^{* * * *}$ Burning and cooking. ${ }^{* * * * *}$ Incinerator.

found, utilizing molecular markers, that diesel impacts in Pittsburgh tend to dominate. The split between diesel and gasoline vehicular impacts at the Minnesota CSN sites from CMB solutions have been found to be inaccurate (Chen et al., 2011) when only regular measurements were used. Chow et al. (2007) suggested that CMB has difficulty making an accurate gasoline-diesel split without organic marker compounds.
Hybrid results tend to find lower secondary contributions than the RM methods, except in Chicago and Pittsburgh for this period (Table S14 in the Supplement; see Table S15 in the Supplement for individual sources' contribution to sulfate and secondary organic carbon (SOC)). While the hybrid and RMs agree well on ammonium sulfates at all six sites (16-37\% vs. $20-38 \%$, Table 6), the hybrid method estimated lower secondary organic carbon ( $4.8 \%$ vs. $11.7 \%$ ) in Atlanta, and they differ the most on secondary nitrate impacts 
January 2004 Average Source Impacts for the Regrouped 13 Sources

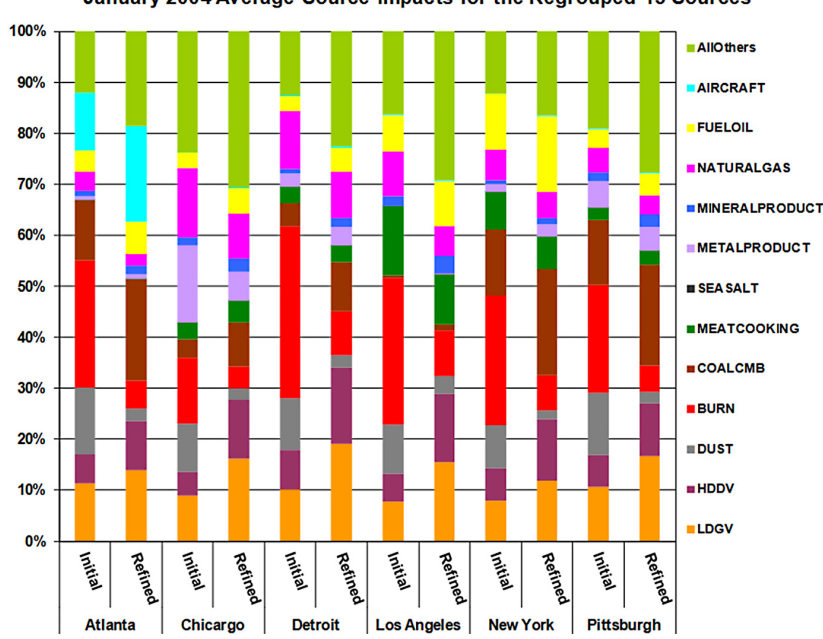

Figure 4. January 2004 average initial and refined source impacts in percentage (\%) of total $\mathrm{PM}_{2.5}$ impact at the six sites for the regrouped 13 sources. Both primary and secondary impacts are included. These 13 sources include 7 unchanged sources from the original 33 sources and 6 newly merged sources, which are (1) LDGV - light-duty gasoline vehicles, merged from NRGASOLINE and ORGASOLINE; (2) HDDV - heavy-duty diesel vehicles, merged from NRDIESEL, ORDIESEL, RAILROAD, and DIESELCMB; (3) BURN - vegetative burning, merged from AGRIBURN, LWASTEBURN, OPENFIRE, PRESCRBU, WILDFIRE, WOODFUEL, and WOODSTOVE; (4) NATURALGAS - merged from NAGASCMB and NRNAGAS; (5) FUELOIL - merged from FUELOILC and NRFUELOI; (6) AllOthers - merged from the leftover hybrid sources: BIOGENIC, LIVESTOCK, LPGCMB, MEXCMB_M, NRLPG, NROTHERS, OTHERCMB, OTHERS, and SOLVENT.

(3-27\% vs. $20-44 \%$, Table 6). The difficulties in simulating particulate nitrate have been noted previously (Chang et al., 2011). The simulated nitrate from CMAQ tended to be biased low in the base simulation at some locations and times. The hybrid method adjusted the nitrate upwards to better match the observed value, but will not force it to an exact match. This is because the adjustment is limited by the second term on the right-hand side of Eq. (12) that penalizes over-adjusting the impact based upon the estimated uncertainty in the emissions (of $\mathrm{NO}_{\mathrm{x}}$ in this case). Given that estimated emissions of $\mathrm{NO}_{\mathrm{x}}$ from power plants are viewed as well estimated and emissions from mobile sources are not as uncertain as, for example, dust emissions, this term will limit the adjustment of impacts from those sources more than other sources. Typical RM methods do not have a similar term for secondary contributions; they allow the attribution of species to secondary contributions to match the observations exactly.

\section{Discussion}

The hybrid source apportionment method developed and applied here has been demonstrated to be a novel way to improve SM-only CTM results by utilizing observations. It also has advantages over RM methods. First, some limitations of RM methods are addressed (depending upon RM method): (1) the assumption that emissions are inert, with no chemical reactions; (2) a limited number of source categories are considered; (3) potential collinearities between source compositions; (4) inconsistent or unrealistic results because receptor models do not include information on the strength and location of source emissions; and (5) not accounting for physical process such as complex meteorology. Second, the refinement and evaluation of the source impact estimates use measurement data that are independent from those used to develop the initial source impact estimates. Additionally, the hybrid method can be applied to obtain spatial fields of source impacts providing refined hourly spatial fields.

A number of potential uncertainties from the CTM modeling can lead to uncertainties in the estimated impacts from the hybrid approach. The assumption for deriving concentrations and sensitivities for the elements that are not explicitly simulated in the CTM model might not always hold. The missing pathways of secondary organic aerosol formation and inaccurate representation of nitrate formation in the CTM model can lead to underestimation of secondary source impacts. Errors in the meteorology may result in errors in the source fingerprints $\left(f_{i, j}^{*}\right)$ and source-receptor relationships. Errors in the initial emissions inventory, particularly in the spatial and/or temporal variability and in the composition of the emissions, also introduce potential errors, particularly when using the model to temporally interpolate the impact adjustments, i.e., to provide $1 \mathrm{~h}$ impact fields after using the $24 \mathrm{~h}$, speciated $\mathrm{PM}_{2.5}$ measurements. Thus, it is best to consider using results of this approach applied to $24 \mathrm{~h}$ averaged fields.

On the other hand, evaluating the hybrid model results on a species basis can help identify errors in the original source profiles. Additionally, including measurements from multiple sites in a region and/or spatially dense satellite retrievals in the process of adjusting emissions can further help stabilize $R_{j}$. This will provide more accurate refinements and address the possibility of the measurements taken at a single point being overly influenced by local sources. In this direction, the hybrid source results can be more accurate representations of the pollutant levels spatially because they integrate estimates of the spatial distribution of emissions and the local chemical and physical atmospheric processes.

The Supplement related to this article is available online at doi:10.5194/acp-14-5415-2014-supplement. 
Acknowledgements. This publication was made possible by funding from the US EPA under grants RD834799 and RD833866, NASA under grant NNX11AI55G, Georgia Power, and Southern Company. Its contents are solely the responsibility of the grantee and do not necessarily represent the official views of the supporting agencies. Further, the US government does not endorse the purchase of any commercial products or services mentioned in the publication.

Edited by: A. Carlton

\section{References}

Appel, K. W., Bhave, P. V., Gilliland, A. B., Sarwar, G., and Roselle, S. J.: Evaluation of the community multiscale air quality (CMAQ) model version 4.5: Sensitivities impacting model performance; Part II - particulate matter, Atmos. Environ., 42, 6057-6066, 2008.

Appel, K. W., Pouliot, G. A., Simon, H., Sarwar, G., Pye, H. O. T., Napelenok, S. L., Akhtar, F., and Roselle, S. J.: Evaluation of dust and trace metal estimates from the Community Multiscale Air Quality (CMAQ) model version 5.0, Geosci. Model Dev., 6, 883-899, doi:10.5194/gmd-6-883-2013, 2013.

Baek, J.: Improving aerosol simulations: Assessing and improving emissions and secondary organic aerosol formation in air quality modeling, 140 pp., Georgia Institute of Tecnology, Atlanta, GA, Ph.D. Dissertation, 2009.

Balachandran, S., Pachon, J. E., Hu, Y., Lee, D., Mulholland, J. A., and Russell, A. G.: Ensemble-trained source apportionment of fine particulate matter and method uncertainty analysis, Atmos. Environ., 61, 387-394, 2012.

Binkowski, F. S. and Roselle, S. J.: Models-3 Community Multi-scale Air Quality (CMAQ) model aerosol component: 1. Model description, J. Geophys. Res., 108, 4183, doi:10.1029/2001JD001409, 2003.

Blanchard, C. L., Tanenbaum, S., and Hidy, G. M.: Source Contributions to Atmospheric Gases and Particulate Matter in the Southeastern United States, Environ. Sci. Technol., 46, 54795488, 2012.

Boylan, J. W. and Russell, A. G.: PM and light extinction model performance metrics, goals, and criteria for three-dimensional air quality models, Atmos. Environ., 40, 4946-4959, 2006.

Boylan, J. W., Odman, M. T., Wilkinson, J. G., Russell, A. G., Doty, K. G., Norris, W. B., and McNider, R. T.: Development of a comprehensive, multiscale "one-atmosphere" modeling system: application to the Southern Appalachian Mountains, Atmos. Environ., 36, 3721-3734, 2002.

Boylan, J. W., Odman, M. T., Wilkinson, J. G., and Russell, A. G.: Integrated assessment modeling of atmospheric pollutants in the Southern Appalachian Mountains: Part II - $\mathrm{PM}_{2.5}$ and visibility, J. Air Waste Manage., 56, 12-22, 2006.

Bullock, K. R., Duvall, R. M., Norris, G. A., McDow, S. R., and Hays, M. D.: Evaluation of the CMB and PMF models using organic molecular markers in fine particulate matter collected during the Pittsburgh Air Quality Study, Atmos. Environ., 42, 68976904, 2008.

Burr, M. J. and Zhang, Y.: Source apportionment of fine particulate matter over the Eastern U.S. Part II: source apportionment simulations using CAMx/PSAT and comparisons with CMAQ source sensitivity simulations, Atmospheric Pollution Research, 2, 318336, doi:10.5094/APR.2011.037, 2011a.

Burr, M. J. and Zhang, Y.: Source apportionment of fine particulate matter over the Eastern U.S. Part I: source sensitivity simulations using CMAQ with the Brute Force method, Atmospheric Pollution Research, 2, 300-317, doi:10.5094/APR.2011.036, $2011 \mathrm{~b}$.

Byun, D. and Schere, K. L.: Review of the Governing Equations, Computational Algorithms, and Other Components of the Models-3 Community Multiscale Air Quality (CMAQ) Modeling System, Appl. Mech. Rev., 59, 51-77, 2006.

Carter, W. P. L.: Documentation of the SAPRC-99 Chemical Mechanism for VOC Reactivity Assessment, Contract No. 92-329 and 95-308, California Air Resources Board, 2000.

CEP: Sparse Matrix Operator Kernel Emissions Modeling System (SMOKE) User Manual, Carolina Environmental Program - The University of North Carolina at Chapel Hill, Chapel Hill, NC, 2003.

Chang, W. L., Bhave, P. V., Brown, S. S., Riemer, N., Stutz, J., and Dabdub, D.: Heterogeneous Atmospheric Chemistry, Ambient Measurements, and Model Calculations of $\mathrm{N}_{2} \mathrm{O}_{5}$ : A Review, Aerosol Sci. Tech., 45, 665-695, 2011.

Chen, L. W. A., Watson, J. G., Chow, J. C., DuBois, D. W., and Herschberger, L.: Chemical mass balance source apportionment for combined $\mathrm{PM}_{2.5}$ measurements from U.S. non-urban and urban long-term networks, Atmos. Environ., 44, 4908-4918, 2010.

Chen, L. W. A., Watson, J. G., Chow, J. C., DuBois, D. W., and Herschberger, L.: $\mathrm{PM}_{2.5}$ Source Apportionment: Reconciling Receptor Models for US Nonurban and Urban Long-Term Networks, J. Air Waste Manage., 61, 1204-1217, 2011.

Chow, J. C., Watson, J. G., Lowenthal, D. H., Solomon, P. A., Magliano, K. L., Ziman, S. D., and Richards, L. W.: PM 10 Source Apportionment in California San-Joaquin Valley, Atmos. Environ. A-Gen., 26, 3335-3354, 1992.

Chow, J. C., Watson, J. G., Lowenthal, D. H., Chen, L. W. A., Zielinska, B., Mazzoleni, L. R., and Magliano, K. L.: Evaluation of organic markers for chemical mass balance source apportionment at the Fresno Supersite, Atmos. Chem. Phys., 7, 17411754, doi:10.5194/acp-7-1741-2007, 2007.

Cohan, D. S., Hakami, A., Hu, Y., and Russell, A. G.: Nonlinear response of ozone to emissions: source apportionment and sensitivity analysis, Environ. Sci. Technol., 39, 6739-6748, 2005.

Cooper, J. A. and Watson, J. G.: Reseptor Oriented Methods of Air Particulate Source Apportionment, JAPCA J. Air Waste Ma., 30, 1116-1125, 1980.

Coutant, B. W., Holloman, C. H., Swinton, K. E., and Hafner, H. R.: Eight-Site Source Apportionment of $\mathrm{PM}_{2.5}$ Speciation Trend Data, EPA Contract No. 68-D-02-061, Work Assignment 1-05, 2003.

Dockery, D. W., Pope, C. A., Xu, X., Spengler, J. D., Ware, J. H., Fay, M. E., Ferris, B. G., and Speizer, F. E.: An Association between Air Pollution and Mortality in Six U.S. Cities, The New England Journal of Medicine, 329, 24, 1753-1759, 1993.

Doraiswamy, P., Davis, W. T., Miller, T. L., and Fu, J. S.: Source apportionment of fine particles in Tennessee using a sourceoriented model, J. Air Waste Manage., 57, 407-419, 2007.

Dunker, A. M.: Efficient Calculation of Sensitivity Coefficients for Complex Atmospheric Models, Atmos. Environ., 15, 1155$1161,1981$. 
Dunker, A. M.: The Decoupled Direct Method for Calculating Sensitivity Coefficients in Chemical-Kinetics, J. Chem. Phys., 81, 2385-2393, 1984.

Dunker, A. M., Yarwood, G., Ortmann, J. P., and Wilson, G. M.: Comparison of source apportionment and source sensitivity of ozone in a three-dimensional air quality model, Environ. Sci. Technol., 36, 2953-2964, 2002.

Emery, C., Tai, E., and Yarwood, G.: Enhanced meteorological modeling and performance evaluation for two Texas ozone episodes, Prepared for the Texas Natural Resource Conservation Commissions, ENVIRON International Corporation, Novato, CA, 2001

Gildemeister, A. E., Hopke, P. K., and Kim, E.: Sources of fine urban particulate matter in Detroit, MI, Chemosphere, 69, 1064 1074, 2007.

Grell, G., Dudhia, J., and Stauffer, D.: A description of the Fifth-Generation Penn State/NCAR Mesoscale Model (MM5), NCAR/TN 398+STR, NCAR Technical Note: NCAR/TN398+STR, 1994.

Hakami, A., Odman, M. T., and Russell, A. G.: Nonlinearity in atmospheric response: A direct sensitivity analysis approach, J. Geophys. Res.-Atmos., 109, D15303, doi:10.1029/2003JD004502, 2004.

Hanna, S., Chang, J., and Fernau, M.: Monte Carlo estimates of uncertainties in predictions by a photochemical grid model (UAMIV) due to uncertainties in input variables, Atmos. Environ., 32, 3619-3628, 1998.

Hanna, S. R. and Yang, R.: Evaluations of mesoscale models' simulations of near-surface winds, temperature gradients, and mixing depths, J. Appl. Meteorol., 40, 1095-1104, 2001.

Hanna, S. R., Lu, Z., Frey, H. C., Wheeler, N., Vukovich, J., Arumachalam, S., and Fernau, M. E.: Uncertainties in predicted ozone concentration due to input uncertainties for the UAM-V photochemical grid model applied to the July 1995 OTAG domain, Atmos. Environ., 35, 891-903, 2001.

Hanna, S. R., Russell, A. G., Wilkinson, J., Vukovich, J., and Hansen, D. A.: Monte Carlo estimation of uncertainties in BEIS3 emission outputs and their effects on uncertainties in Chemical Transport Model predictions, J. Geophys. Res., 110, D01302, doi:10.01029/2004JD004986, 2005.

Held, T., Ying, Q., Kleeman, M. J., Schauer, J. J., and Fraser, M. P.: A comparison of the UCD/CIT air quality model and the CMB source-receptor model for primary airborne particulate matter, Atmos. Environ., 39, 2281-2297, 2005.

Henze, D. K., Seinfeld, J. H., and Shindell, D. T.: Inverse modeling and mapping US air quality influences of inorganic $\mathrm{PM}_{2.5}$ precursor emissions using the adjoint of GEOS-Chem, Atmos. Chem. Phys., 9, 5877-5903, doi:10.5194/acp-9-5877-2009, 2009.

Herndon, S. C., Jayne, J. T., Lobo, P., Onasch, T. B., Fleming, G., Hagen, D. E., Whitefield, P. D., and Miake-Lye, R. C.: Commercial aircraft engine emissions characterization of in-use aircraft at Hartsfield-Jackson Atlanta International Airport, Environ. Sci. Technol., 42, 1877-1883, 2008.

Hu, Y., Odman, M. T., and Russell, A. G.: Mass conservation in the Community Multiscale Air Quality model, Atmos. Environ., 40, 1199-1204, 2006.

Kleeman, M. J., Ying, Q., Lu, J., Mysliwiec, M. J., Griffin, R. J., Chen, J. J., and Clegg, S.: Source apportionment of secondary organic aerosol during a severe photochemical smog episode, Atmos. Environ., 41, 576-591, 2007.

Koo, B., Wilson, G. M., Morris, R. E., Dunker, A. M., and Yarwood, G.: Comparison of Source Apportionment and Sensitivity Analysis in a Particulate Matter Air Quality Model, Environ. Sci. Technol., 43, 6669-6675, 2009.

Kraft, D.: A software package for sequential quadratic programming, Technical Report DFVLR-FB 88-28, Institut für Dynamik der Flugsysteme, Oberpfaffenhofen, July, 1988.

Kraft, D.: Algorithm 733: TOMP-Fortran modules for optimal control calculations, ACM T. Math. Software, 20, 262-281, 1994.

Kwok, R. H. F., Napelenok, S. L., and Baker, K. R.: Implementation and evaluation of $\mathrm{PM}_{2.5}$ source contribution analysis in a photochemical model, Atmos. Environ., 80, 398-407, 2013

Laupsa, H., Denby, B., Larssen, S., and Schaug, J.: Source apportionment of particulate matter $\left(\mathrm{PM}_{2.5}\right)$ in an urban area using dispersion, receptor and inverse modelling, Atmos. Environ., 43, 4733-4744, 2009.

Lee, B. H., Wood, E. C., Miake-Lye, R. C., Herndon, S. C., Munger, J. W., and Wofsy, S. C.: Reactive Chemistry in Aircraft Exhaust Implications for Air Quality, Transp. Res. Record, 2206, 19-23, 2011.

Lee, D., Balachandran, S., Pachon, J., Shankaran, R., Lee, S., Mulholland, J. A., and Russell, A. G.: Ensemble-Trained PM 2.5 Source Apportionment Approach for Health Studies, Environ. Sci. Technol., 43, 7023-7031, 2009.

Lee, S. and Russell, A. G.: Estimating uncertainties and uncertainty contributors of $\mathrm{CMB} \mathrm{PM}_{2.5}$ source apportionment results, Atmos. Environ., 41, 9616-9624, 2007.

Lee, S., Liu, W., Wang, Y. H., Russell, A. G., and Edgerton, E. S.: Source apportionment of $\mathrm{PM}_{2.5}$ : Comparing PMF and CMB results for four ambient monitoriniz sites in the southeastern United States, Atmos. Environ., 42, 4126-4137, 2008.

Lin, C. and Milford, J. B.: Decay-Adjusted Chemical Mass-Balance Receptor Modeling for Volatile Organic-Compounds, Atmos. Environ., 28, 3261-3276, 1994.

Liu, D. C. and Nocedal, J.: On the Limited Memory Method for Large Scale Optimization, Mathematical Programming B, 45, 503-528, 1989.

Liu, W., Wang, Y. H., Russell, A., and Edgerton, E. S.: Enhanced source identification of southeast aerosols using temperatureresolved carbon fractions and gas phase components, Atmos. Environ., 40, S445-S466, 2006.

Lowenthal, D. H., Watson, J. G., Koracin, D., Chen, L. W. A., Dubois, D., Vellore, R., Kumar, N., Knipping, E. M., Wheeler, N., Craig, K., and Reid, S.: Evaluation of Regional-Scale Receptor Modeling, J. Air Waste Manage., 60, 26-42, 2010.

Malm, W. C., Schichtel, B. A., and Pitchford, M. L.: Uncertainties in $\mathrm{PM}_{2.5}$ gravimetric and speciation measurements and what we can learn from them, J. Air Waste Manage., 61, 1131-1149, 2011.

Maranche, J.: Allegheny County $\mathrm{PM}_{2.5}$ Source Apportionment Results using the Positive Matrix Factorization Model, Allegheny County Health Department, Pittsburgh, PA (http://www.achd.net/ airqual/pubs/pdf/pmf0106.pdf), 2006.

Marmur, A., Unal, A., Mulholland, J. A., and Russell, A. G.: Optimization-based source apportionment of $\mathrm{PM}_{2.5}$ incorporating gas-to-particle ratios, Environ. Sci. Technol., 39, 3245-3254, 2005. 
Marmur, A., Park, S. K., Mulholland, J. A., Tolbert, P. E., and Russell, A. G.: Source apportionment of $\mathrm{PM}_{2.5}$ in the southeastern United States using receptor and emissions-based models: Conceptual differences and implications for time-series health studies, Atmos. Environ., 40, 2533-2551, 2006.

Marmur, A., Mulholland, J. A., and Russell, A. G.: Optimized variable source-profile approach for source apportionment, Atmos. Environ., 41, 493-505, 2007.

Martello, D. V., Pekney, N. J., Anderson, R. R., Davidson, C. I., Hopke, P. K., Kim, E., Christensen, W. F., Mangelson, N. F., and Eatough, D. J.: Apportionment of ambient primary and secondary fine particulate matter at the Pittsburgh National Energy Laboratory particulate matter characterization site using positive matrix factorization and a potential source contributions function analysis, J. Air Waste Manage., 58, 357-368, 2008.

Martin, D., Petersson, K. F., and Shallcross, D. E.: The use of cyclic perfluoroalkanes and $\mathrm{SF}_{6}$ in atmospheric dispersion experiments, Q. J. Ror. Meteor. Soc., 137, 2047-2063, 2011.

Napelenok, S. L., Cohan, D., Hu, Y., and Russell, A. G.: Decoupled Direct 3D Sensitivity Analysis For Particulate Matter (DDM3D/PM), Atmos. Environ., 40, 6112-6121, 2006.

Nocedal, J.: Updating Quasi-Newton Matrices with Limited Storage, Math. Comput., 35, 773-782, 1980.

Pattero, P. and Tapper, U.: Positive Matrix Factorization - a Nonnegative Factor Model with Optimal Utilization of ErrorEstimates of Data Values, Environmetrics, 5, 111-126, 1994.

Pham, T.-L., Kim, B. M., Katzenstein, A., and Goss, T.: PM 2.5 Source Apportionment for the South Coast Air Basin Using Chemical Mass Balance Receptor Model, MATES III Final Report, available at: http://www.aqmd.gov/prdas/matesIII/Final/ Appendices/g-MATESIIIAppendixVIIFina192008.pdf (last access: 16 May 2013), 2008.

Pleim, J. E. and Xiu, A.: Development and testing of a surface flux and planetary boundary layer model with explicit soil moisture parameterization for application in mesoscale models, J. Appl. Meteorol., 34, 16-32, 1995.

Reff, A., Eberly, S. I., and Bhave, P. V.: Receptor modeling of ambient particulate matter data using positive matrix factorization: Review of existing methods, J. Air Waste Manage., 57, 146-154, 2007.

Reff, A., Bhave, P. V., Simon, H., Pace, T. G., Pouliot, G. A., Mobley, J. D., and Houyoux, M.: Emissions Inventory of $\mathrm{PM}_{2.5}$ Trace Elements across the United States, Environ. Sci. Technol., 43, 5790-5796, 2009.

Rizzo, M. J., and Scheff, P. A.: Fine particulate source apportionment using data from the USEPA speciation trends network in Chicago, Illinois: Comparison of two source apportionment models, Atmos. Environ., 41, 6276-6288, 2007.

Roy, A. A., Wagstrom, K. M., Adams, P. J., Pandis, S. N., and Robinson, A. L.: Quantification of the effects of molecular marker oxidation on source apportionment estimates for motor vehicles, Atmos. Environ., 45, 3132-3140, 2011.

Russell, A. G.: EPA Supersites Program-related emissions-based particulate matter modeling: Initial applications and advances, J. Air Waste Manage., 58, 289-302, 2008.

Schauer, J. J., Rogge, W. F., Hildemann, L. M., Mazurek, M. A., and Cass, G. R.: Source apportionment of airborne particulate matter using organic compounds as tracers, Atmos. Environ., 30, 3837-3855, 1996.
Schichtel, B. A., Malm, W. C., Gebhart, K. A., Barna, M. G., and Knipping, E. M.: A hybrid source apportionment model integrating measured data and air quality model results, J. Geophys. Res.-Atmos., 111, D07301, doi:10.1029/2005JD006238, 2006.

Sheesley, R. J., Schauer, J. J., Zheng, M., and Wang, B.: Sensitivity of molecular marker-based CMB models to biomass burning source profiles, Atmos. Environ., 41, 9050-9063, 2007.

Shi, G. L., Li, X., Feng, Y. C., Wang, Y. Q., Wu, J. H., Li, J., and Zhu, T.: Combined source apportionment, using positive matrix factorization-chemical mass balance and principal component analysis/multiple linear regression-chemical mass balance models, Atmos. Environ., 43, 2929-2937, 2009.

Simon, H., Beck, L., Bhave, P. V., Divita, F., Hsu, Y., Luecken, D., Mobley, J. D., Pouliot, G. A., Reff, A., Sarwar, G., and Strum, M.: The development and uses of EPA's SPECIATE database, Atmospheric Pollution Research, 1, 196-206, 2010.

Simon, H., Baker, K. R., and Phillips, S.: Compilation and interpretation of photochemical model performance statistics published between 2006 and 2012, Atmos. Environ., 61, 124-139, 2012.

Subramanian, R., Donahue, N. M., Bernardo-Bricker, A., Rogge, W. F., and Robinson, A. L.: Contribution of motor vehicle emissions to organic carbon and fine particle mass in Pittsburgh, Pennsylvania: Effects of varying source profiles and seasonal trends in ambient marker concentrations, Atmos. Environ., 40, 8002-8019, 2006.

Subramanian, R., Donahue, N. M., Bernardo-Bricker, A., Rogge, W. F., and Robinson, A. L.: Insights into the primary-secondary and regional-local contributions to organic aerosol and $\mathrm{PM}_{2.5}$ mass in Pittsburgh, Pennsylvania, Atmos. Environ., 41, 74147433, 2007.

Swietlicki, E., Puri, S., Hansson, H. C., and Edner, H.: Urban air pollution source apportionment using a combination of aerosol and gas monitoring techniques, Atmos. Environ., 30, 2795-2809, 1996.

Tesche, T. W., Morris, R., Tonnesen, G., McNally, D., Boylan, J., and Brewer, P.: CMAQ/CAMx annual 2002 performance evaluation over the eastern US, Atmos. Environ., 40, 4906-4919, 2006.

Thurston, G. D., Ito, K., and Lall, R.: A source apportionment of U.S. fine particulate matter air pollution, Atmos. Environ., 45, 3924-3936, 2011.

Tian, D., Hu, Y., Wang, Y., Boylan, J., Zheng, M., and Russell, A. G.: Assessment of Biomass Burning Emissions and Their Impacts on Urban and Regional $\mathrm{PM}_{2.5}$ : A Georgia Case Study, Environ. Sci. Technol., 43, 299-305, doi:210.1021/es801827s, 2009.

Unal, A., Hu, Y. T., Chang, M. E., Odman, M. T., and Russell, A. G.: Airport related emissions and impacts on air quality: Application to the Atlanta International Airport, Atmos. Environ., 39, 5787 5798, 2005.

USEPA: Protocol for Applying and Validating the CMB Model for $\mathrm{PM}_{2.5}$ and VOC, Report Number EPA-451/R-04-001, U.S. Environmental Protection Agency, Research Triangle Park, NC, 2004.

Viana, M., Pandolfi, M., Minguillon, M. C., Querol, X., Alastuey, A., Monfort, E., and Celades, I.: Inter-comparison of receptor models for PM source apportionment: Case study in an industrial area, Atmos. Environ., 42, 3820-3832, 2008a.

Viana, M., Kuhlbusch, T. A. J., Querol, X., Alastuey, A., Harrison, R. M., Hopke, P. K., Winiwarter, W., Vallius, A., Szidat, S., Prevot, A. S. H., Hueglin, C., Bloemen, H., Wahlin, P., Vecchi, R., Miranda, A. I., Kasper-Giebl, A., Maenhaut, W., and 
Hitzenberger, R.: Source apportionment of particulate matter in Europe: A review of methods and results, J. Aerosol Sci., 39, 827-849, 2008b.

Wagstrom, K. M., Pandis, S. N., Yarwood, G., Wilson, G. M., and Morris, R. E.: Development and application of a computationally efficient particulate matter apportionment algorithm in a three-dimensional chemical transport model, Atmos. Environ., 42, 5650-5659, 2008.

Wang, Z. S., Chien, C. J., and Tonnesen, G. S.: Development of a tagged species source apportionment algorithm to characterize three-dimensional transport and transformation of precursors and secondary pollutants, J. Geophys. Res.-Atmos., 114, D21206, doi:10.1029/2008JD010846, 2009.

Watson, J. G.: Overview of Receptor Model Principles, J. Air Pollut. Control Assoc., 34, 619-623, 1984.

Watson, J. G., Cooper, J. A., and Huntzicker, J. J.: The Effective Variance Weighting for Least-Squares Calculations Applied to the Mass Balance Receptor Model, Atmos. Environ., 18, $1347-$ 1355,1984

Watson, J. G., Chen, L. W. A., Chow, J. C., Doraiswamy, P., and Lowenthal, D. H.: Source apportionment: Findings from the US Supersites program, J. Air Waste Manage., 58, 265-288, 2008.

Watson, J. G., Chow, J. C., Lowenthal, D. H., Robinson, N. F., Cahill, C. F., and Blumenthal, D. L.: Simulating changes in source profiles from coal-fired power stations: Use in chemical mass balance of $\mathrm{PM}_{2.5}$ in the Mount Zirkel Wilderness, Energy \& Fuels, 16, 311-324, 2002.

Wittig, A. E. and Allen, D. T.: Improvement of the Chemical Mass Balance model for apportioning - sources of non-methane hydrocarbons using composite aged source profiles, Atmos. Environ., 42, 1319-1337, 2008.
Xie, M. J., Piedrahita, R., Dutton, S. J., Milford, J. B., Hemann, J. G., Peel, J. L., Miller, S. L., Kim, S. Y., Vedal, S., Sheppard, L., and Hannigan, M. P.: Positive matrix factorization of a 32month series of daily $\mathrm{PM}_{2.5}$ speciation data with incorporation of temperature stratification, Atmos. Environ., 65, 11-20, 2013.

Xiu, A. and Pleim, J. E.: Development and application of a landsurface model. I: Application in a mesoscale meteorology model, J. Appl. Meteorol., 40, 192-209, 2001.

Yang, Y.-J., Wilkinson, J., and Russell, A. G.: Fast, direct sensitivity analysis of multidimensional photochemical models, Environ. Sci. Technol. 31, 2859-2868, 1997.

Ying, Q., Lu, J., Kaduwela, A., and Kleeman, M.: Modeling air quality during the California Regional $\mathrm{PM}_{10} / \mathrm{PM}_{2.5}$ Air Quality Study (CPRAQS) using the UCD/CIT Source Oriented Air Quality Model - Part II. Regional source apportionment of primary airborne particulate matter, Atmos. Environ., 42, 89678978, 2008.

Zhang, W., Capps, S. L., Hu, Y., Nenes, A., Napelenok, S. L., and Russell, A. G.: Development of the high-order decoupled direct method in three dimensions for particulate matter: enabling advanced sensitivity analysis in air quality models, Geosci. Model Dev., 5, 355-368, doi:10.5194/gmd-5-355-2012, 2012.

Zheng, M., Cass, G. R., Schauer, J. J., and Edgerton, E. S.: Source apportionment of $\mathrm{PM}_{2.5}$ in the southeastern United States using solvent-extractable organic compounds as tracers, Environ. Sci Technol., 36, 2361-2371, 2002. 